\title{
FINANCIRANJE JEDINICA LOKALNE I PODRUČNE (REGIONALNE) SAMOUPRAVE
}

\author{
UDK: $35: 336(497.5)$ \\ Primljeno: 1. rujna 2018. \\ Pregledni rad
}

Teritorijalna organizacija suvremenih država počiva na načelima decentralizacije, što obuhvaća političku, upravnu i financijsku neovisnost nižih razina vlasti. Temeljno je načelo da ni jedna funkcija, ni jedan posao ni zadatak ne može se dodijeliti određenoj razini vlasti ili tijelu državne vlasti a da se za to ne osiguraju novčana sredstva. Jedinice lokalne i područne (regionalne) samouprave predstavljaju jedno od strateški važnih područja ključnih za razvoj demokratskih i kvalitetnih javnih politika Republike Hrvatske. Odnos između jedinica lokalne i područne (regionalne) samouprave i korisnika može se promatrati i kao usporedni proces jačanja odgovornosti lokalnih jedinica za ukupnu kakvoću i ,ponudu“ javnih usluga na lokalnom području. Stoga jedinice lokalne i područne (regionalne) samouprave imaju pravo na različite izvore financiranja kako bi mogle obavljati poslove iz svoje nadležnosti odnosno pružiti u većoj ili manjoj mjeri kvalitetnije javne usluge svojim korisnicima.

Ključne riječi: financiranje, jedinice lokalne i područne (regionalne) samouprave, decentralizacija, fiskalna decentralizacija

\section{UVOD}

S gledišta teritorijalne organizacije, standardno je rješenje i uobičajeni obrazac u većem broju suvremenih država - postojanje triju razina vlasti (administrativnih razina): središnjih, područnih i lokalnih vlasti (administracija). ${ }^{1}$

Demokratsko načelo, zajedničko svim državama, jest pravo građana da sudjeluju u upravljanju javnim poslovima. Stupanj demokracije određenog sustava očituje se na području funkcioniranja lokalne i područne (regionalne) samouprave (Z. Š.) koja je jedan od segmenata pravno uređenoga društva, u kojem se očituje zadovoljavanje potreba, prije svega pojedinaca, pa time i efikasnost kolektiviteta kojem pripada, a sve zajedno pridonosi uspjehu društva u cjelini. ${ }^{2}$

1 H. Arbutina, IV. poglavlje „Financijsko izravnanje“ u: Bo. Jelčić i drugi, Financijsko pravo $i$ financijska znanost, Narodne novine, Zagreb, 2008., str. 644.

2 B. Mauhar, „Lokalna samouprava u Republici Hrvatskoj između htijenja i mogućnosti“ u: Zborniku radova s međunarodnog znanstvenog skupa Uloga države u socio-ekonomskom razvoju nacionalnog gospodarstva u povodu 80. godišnjice života prof. emeritusa Božidara Jelčića, Visoka poslovna škola Libertas u Zagrebu, Zagreb, 2010., str. 200. 
Reformama lokalne samouprave u suvremenoj Europi pokušava se ostvariti ravnoteža među težnjama za demokratizacijom i efikasnošću javnih vlasti. ${ }^{3}$

Drugim riječima, bitno je uočiti da se država brine o javnim potrebama i javnim funkcijama i da raspodjeljuje zadovoljavanje tih potreba i funkcija svakoj razini vlasti, određujući njihove međusobne odnose u ostvarivanju javnih funkcija. Istovremeno država određuje i pravo na odgovarajuće javne rashode kojima se te funkcije moraju financirati, a to znači da se za obavljanje konkretnih javnih funkcija moraju za sve korisnike javnih odnosno proračunskih sredstava osigurati odgovarajuća financijska sredstva u proračunu. ${ }^{4}$

Države u razvijenim zemljama sve odreda vode računa o novoj situaciji nastaloj procesom globalizacije i nastoje svoje strukture i metode tome prilagoditi. Smjernice za budući razvitak javne uprave obuhvaćaju ograničenje ukupnog opsega javnog sektora, daljnju privatizaciju, daljnju komercijalizaciju (pretvaranje javnih tijela u društva načelno izjednačena s gospodarskim organizacijama), daljnje prenošenje ovlasti na regionalne i lokalne institucije, uvođenje mehanizama tržišnog tipa u javnu upravu, suženu ulogu središnjih tijela državne uprave, uvođenje sustavnog planiranja i razvijanje programa u politici, sustavnu kontrolu uspješnosti, restrukturiranje financija i politike osoblja, nova načela i metode donošenja podzakonskih akata, poboljšanje odnosa s građanima i poduzećima, puno iskorištenje informatičke tehnologije. 5

Treba posebno naglasiti da lokalna i područna (regionalna) samouprava ima važnu ulogu u upravljanju, organizaciji i izravnom pružanju javnih usluga građanima. U nastojanju izgradnje djelotvorne, učinkovite i ekonomične javne uprave potrebno je uspostaviti i djelotvoran sustav lokalne i područne (regionalne) samouprave ${ }^{6} \mathrm{u}$ upravnom i financijskom smislu. Stoga će u nastavku ovoga rada biti više riječi o fiskalnoj decentralizaciji odnosno o pravnim aspektima financiranja jedinica lokalne i područne (regionalne) samouprave u Republici Hrvatskoj (de lege lata - de lege ferenda) i u odabranim državama.

\section{OPĆENITO O POJMU FISKALNA DECENTRALIZACIJA}

Fiskalna decentralizacija je prenošenje odlučivanja o raspodjeli javnih rashoda i javnih prihoda na pojedine razine vlasti. Radi se o primjeni fiskalnog suvereniteta u širem smislu (prenošenje i/ili podjela vlasti nad javnim prihodima i javnim rashodima) i o primjeni fiskalnog suvereniteta u užem smislu (prenošenje i/ili

\footnotetext{
3 I. Koprić, „Decentralizacija i dobro upravljanje gradovima“, Hrvatska javna uprava, god. 9., br. 1/2009., Pravni fakultet Sveučilišta u Zagrebu, Zagreb, 2009., str. 70.

4 J. Gorčić, Fiskalni federalizam, lokalna samouprava i budžetske politike, Evropski centar za mir i razvoj Univerziteta za mir Ujedinjenih nacija, Institut za poslovne finansije, Beograd, 2013., str. 14.

5 E. Pusić, Država i državna uprava, Pravni fakultet u Zagrebu, Zagreb, 1999., str. 273.

6 Podrobnije vidjeti u: Strateški plan Ministarstva uprave za razdoblje 2019. - 2021. godine, Ministarstvo uprave, Zagreb, 2018., str. 1.-25.
} 
podjela vlasti nad javnim prihodima, odnosno moći nad novcem kojim se financiraju javne potrebe). ${ }^{\text {? }}$

„Fiskalna decentralizacija je u modi. Industrijske i nacije u razvoju okreću se devoluciji da bi unaprijedile uspješnost svojih javnih sektora“. Tim je riječima, Wallace Oates, američki ekonomist i jedan od najrenomiranijih svjetskih autora o pitanjima fiskalne decentralizacije upozorio u svom preglednom članku o fiskalnom federalizmu ${ }^{8}$ iz 1999. godine da je decentralizacija, u različitim svojim oblicima, postala svjetskim fenomenom, poput globalizacije. ${ }^{9}$

Fiskalna decentralizacija potiče „konkurenciju“ između nižih političkoteritorijalnih jedinica: svaka od ovih jedinica nastojat će što bolje zadovoljiti potrebe svog stanovništva kako ne bi došlo do pojave migracije u jedinice u kojima je osiguravanje javnih dobara bolje, jeftinije ili u kojima građani mogu uživati dobra koja se ne osiguravaju u jedinici njihova prebivališta itd. Na ovaj način potiče se inovacija, a time i bolje osiguravanje javnih dobara. Međutim, to se može ostvariti samo ukoliko između lokalnih jedinica postoji ,zdrava konkurencija“. ${ }^{10}$ Zacijelo nije nekorisno imati u vidu i rezultate empirijskih istraživanja koja pokazuju kako u zemljama s većim udjelima lokalnih rashoda i, posredno, s većom lokalnom autonomijom, lokalne razine imaju veću samostalnost u odlučivanju. ${ }^{11}$

Fiskalna decentralizacija dugotrajan je i složen proces čiju dinamiku uvjetuje niz čimbenika. Proces fiskalne decentralizacije načelno podrazumijeva selektivan, osmišljen i financijski potkrijepljen prijenos poslova, nadležnosti i ovlasti s državne, dakle središnje vlasti na niže razine vlasti kao nositelje vlasti na lokalnoj razini. Svrha fiskalne decentralizacije jest davanje potpune ovlasti i odgovornosti za donošenje odluka u pogledu financiranja, upravljanja i izvršavanja poslova nižim raznima vlasti, pri čemu u odnosu na prenesene poslove lokalna razina djeluje slobodno i u svom lokalnom interesu. ${ }^{12}$ Temeljno teorijsko opravdanje za provođenje

7 J. Gorčić, Fiskalni... o. c., str. 22.

8 Bez poznavanja i efikasne primjene teorije fiskalnog federalizma i lokalne samouprave ne mogu se ostvariti dostignuća u upravljanju javnim rashodima i javnim prihodima u suvremenim demokratskim državama. Fiskalni federalizam i lokalna samouprava ukazuju na to da je suvremena država organizirana, da je podijeljena fiskalna vlast i da se provodi pasivno (kada su u pitanju javne funkcije i javni rashodi) i aktivno (kada su u pitanju javni prihodi) izravnanje unutar državne organizacije i između države i samouprave kako bi se dostigli optimumi u upravljanju javnim rashodima i prihodima. Podrobnije vidjeti u: T. Hart i drugi, „Fiscal decentralisation“, A public financial management introductory guide, Overseas Development Institute, London, 2016., str. 7-21.

9 Z. Petak, „Politika decentralizacije kao svjetski trend“, Lokalna samouprava pred reformskim izazovima, Vodič kroz lokalnu demokraciju, Stina, Split, 2005., str. 23.

10 S. Burki i drugi, Beyond the Center: Decentralizing the State, The World Bank Washington D. C., 1999., str. 3., R. Ebel i drugi, Fiscal Decentralization: Is It Happening? How Do We Know?, Andrew Young School of Policy Studies, Georgia State University, Atlanta, GA, USA, 2001., str. 18., D. Rondinelli, „What is Decentralization?" in: J. Litvack and J. Seddon (editors), Decentralization Briefing Notes, The World Bank Institute, Washington D. C., 2000., str. 4-5, J. Litvack i drugi, Rethinking Decentralization in Developing Countries, The World Bank Washington D. C., 1998., str. 5.

11 M. Bouvier, Introduction au droit fiscal général et à la théorie de limpôt, LGDJ lextenso editions, Paris, 2010., str. 206.

12 T. Šimić i drugi, „Fiskalna decentralizacija i pitanje teritorijalnog izravnanja u Republici Hrvatskoj“, Pravo i porezi, br. 3/2008., str. 66-72. 
fiskalne decentralizacije s jedne je strane približavanje procesa donošenja odluka (o potrošnji i oporezivanju) građanima, čime javne službe postaju učinkovitije odnosno efikasnije, a s druge strane otklanjanje, sustavom kontrola, svih možebitnih zlouporaba prilikom provedbe procesa fiskalne decentralizacije.

\section{FINANCIRANJE JEDINICA LOKALNE SAMOUPRAVE U ODABRANIM DRŽAVAMA ČLANICAMA EUROPSKE UNIJE}

Posebnosti fiskalne decentralizacije odnosno fiskalnog federalizama u Europskoj uniji rezultat su: 1) specifične raspodjele fiskalnih nadležnosti između država članica i Europske unije kao supranacionalne složene zajednice, 2) posebnosti samog proračuna Europske unije kao takvog, 3) posebnosti politike javnih rashoda i politike javnih prihoda, 4) posljedično tome, i posebnosti fiskalne politike u ostvarivanju alokacijskih, redistribucijskih i stabilizacijskih ciljeva. ${ }^{13}$

Porezna autonomija lokalnih vlasti država članica Europske unije može se sagledati na: 1) države u kojima lokalne vlasti imaju značajno sudjelovanje (participaciju) u ukupnom oporezivanju i veliku autonomiju u njezinu uređivanju (Śvedska, Danska, Španjolska, Belgija, Njemačka i Finska), 2) države s visokim stupnjem autonomije po obimu poreznih prihoda ali su ograničene u pravima uvođenja (nametanja) poreza (Litva, Austrija i Rumunjska), 3) države u kojima lokalne vlasti imaju značajnu snagu uvoditi (nametati) poreze, ali njihovi porezni prihodi ograničeni su odnosno mali (Luksemburg, Nizozemska, Engleska, Francuska i Mađarska), 4) države u kojima subcentralne vlasti imaju samo malo učešće u ukupnim poreznim prihodima i također, ograničenu snagu odlučivanja da ih uvode (nameću) i određuju njihove subjektivne i objektivne karakteristike (Grčka, Irska, Bugarska, Slovenija i Hrvatska). ${ }^{14}$

\section{1. Savezna Republika Njemačka}

Nakon reintegracije istočnih zemalja, Savezna Republika Njemačka sastoji se od 16 saveznih (federalnih) jedinica odnosno 13 zemalja (Länder) i 3 grada koji imaju položaj zemalja (Berlin, Bremen i Hamburg). Savezne jedinice imaju gotovo potpunu autonomiju u reguliranju lokalne samouprave te samostalno uređuju

13 Podrobnije vidjeti u: H. Šimović, „Fiskalni federalizam u Europskoj uniji: odnosi fiskalne nadležnosti“, Zbornik radova Pravnog fakulteta u Zagrebu, god. 55., br. 2/2005., Pravni fakultet Sveučilišta u Zagrebu, Zagreb, 2005., str. 449-479.

14 Podrobnije o fiskalnoj autonomiji protiv fiskalnog federalizma u eurozoni vidjeti u: A. H. Hallett, „Fiscal autonomy vs. Fiscal federalism in the euro zone“, Economia Politica, Volume 34., Issue 2/2017., Journal of Analytical and Institutional Economics, Springer International Publishing Switzerland, 2017. str. $179-188$. 
temeljne institucionalne parametre za djelovanje lokalne samouprave (teritorijalnu podjelu, granice jedinica, statute općina). ${ }^{15}$

Lokalna samouprava organizirana je tradicionalno u dva stupnja. Osnovne jedinice lokalne samouprave su općine (Gemeinden) kojih nakon ujedinjenja ima $12.066 .{ }^{16}$

Općine se nalaze u sustavu 301 zemaljskog okruga (Landkreise) ${ }^{17}$ koji su ujedno i drugostupanjske samoupravne jedinice $i$ administrativne jedinice zemaljske uprave. Veći gradovi imaju status okružnih gradova (Kreisfreie Städte), a ima ih 117. Oni obavljaju poslove iz djelokruga općina i okruga te su izravno pod nadzorom zemaljske vlasti i uprave. ${ }^{18}$

Postoje i stanovita odstupanja od dvostupanjske strukture lokalne samouprave. Glavna odstupanja u smjeru jednostupanjske organizacije jesu tri najveća grada koji imaju status federalnih jedinica. Berlin i Hamburg objedinjuju na razini grada funkcije zemaljske uprave i lokalne samouprave. Poslovi gradske uprave u oba su grada zbog decentralizacije podijeljeni na gradske kotare (Stadtbezirke). Nešto je drugačija situacija s trećim gradom, Bremenom, koji zapravo obuhvaća dva okružna grada, Bremen i Bremenheven (Oldenburg), ali je i ovdje lokalna samouprava organizirana u jednom stupnju. ${ }^{19}$

Čl. 28. Temeljnog zakona Savezne Republike Njemačke ${ }^{20}$ zajamčuje jedinicama lokalne samouprave pravo uređivanja svih lokalnih pitanja na vlastitu odgovornost, u granicama propisanima zakonom. ${ }^{21} \mathrm{U}$ okviru granica njihovih funkcija predviđenih zakonom, udruženja općina također imaju pravo na samoupravu u skladu sa zakonima. Garancija samouprave obuhvaća i pravo na financijsku autonomiju,

15 G. Marčetić i drugi, „Lokalna samouprava u Njemačkoj i Francuskoj“, Hrvatska javna uprava, god. 10., br. 1/2010., Pravni fakultet Sveučilišta u Zagrebu, Zagreb, 2010., str. 68.

16 C. Conroy, „Fiscal and Federal Structures in Germany“ in: T. T. Minassian i drugi, Fiscal Federalism and Governance in the European Union, Project on 21 st Century City Governance, Global Economy and Development at Brookings, 2017., str. 46.

17 R. Manojlović, „Javna uprava i politički sustav Savezne Republike Njemačke: modernizacija kroz očuvanje tradicije“, Hrvatska i komparativna javna uprava, god. 15., br. 1/2015., Institut za javnu upravu, Zagreb, 2015., str. 150.

18 G. Marčetić i drugi, Lokalna... o. c., str. 68

19 U zemljama koje imaju više od 20 okruga i okružnih gradova, zemaljske vlasti formirale su svoje regionalne administrativne jedinice (Regierungsbezirke) preko kojih provode nadzor nad lokalnom samoupravom. Dvije zapadne zemlje, Nordrhein-Westfalen i Rheinland-Pfalz, radikalno su reformirale svoje srednje upravne jedinice pretvorivši ih u jedinice kojih je uloga služenje lokalnoj vlasti, a ne više nadzor. Primjetna je tendencija prema ukidanju te razine te dodatnog jačanja lokalne samouprave. Navedeno prema: ibid., str. 69-70.

20 Grundgesetz für die Bundesrepublik Deutschland vom 23. Mai 1949., (BGB1. S. 1), zuletzt geändert durch Artikel 1. des Gesetzes vom 13. Juli 2017. (BGB1. I S. 2347).

21 Iz navedenoga se može zaključiti da je, sukladno ustavnoj tradiciji koja datira još iz 19. stoljeća, djelokrug samoupravnih poslova općina i okruga uređen metodom opće klauzule (čl. 28. Temeljnog zakona Savezne Republike Njemačke). Pravo lokalnih jedinica da samostalno odlučuju o unutarnjoj organizaciji i modernizaciji lokalne samouprave smatra se temeljnim obilježjem lokalne autonomije; to u velikoj mjeri isključuje mogućnost upletanja i utjecaja savezne i zemaljske razine na organizaciju i poslove lokalne samouprave. 
pri čemu to uključuje pravo općina na vlastite izvore poreznih prihoda i pravo određivanja stope po kojoj se vrši oporezivanje ovih izvora.

U skladu s gore navedenim, prema čl. 104. st. 1. Temeljnog zakona Savezne Republike Njemačke, odgovornost za potrošnju odnosi se na dio vlade koji upravlja određenim javnim poslovima (ali koji ne prouzrokuje trošak). To pravilo koje utvrđuje odnose između savezne vlade i saveznih (federalnih) jedinica - zemalja primjenjuje se i na odnose između vlada saveznih (federalnih) jedinica - zemalja i lokalnih vlasti.

Odnosno u Saveznoj Republici Njemačkoj jedinice lokalne samouprave imaju pravo na različite izvore financiranja kojima financiraju vlastite rashode. Većina tih prihoda potječe od oporezivanja, te drugih financijskih izdvajanja. Osim toga, među izvorima financiranja su: prihodi od pristojbi i naknada, prihodi od aktivnosti (poslovanja) trgovačkih društava i koncesijskih naknada.

Temeljni zakon Savezne Republike Njemačke propisuje načela koja reguliraju oporezivanje u sljedećim člancima: 1) načelo sposobnosti plaćanja i jednakosti u oporezivanju (čl. 3. st. 1.), 2) načelo zakonitosti oporezivanja (čl. 2. st. 1. i čl. 20. st. 3.), 3) načelo socijalne države (čl. 20.).

Temeljni zakon Savezne Republike Njemačke regulira porezna ovlaštenja u sljedećim člancima:

1) Savezna Republika Njemačka ima pravo na prihode od: carina, poreza na motorna vozila, poreza na alkoholna pića, poreza na destilirana pića, poreza na proizvode od mineralnih ulja, poreza na kavu, poreza na vino, poreza na duhanske proizvode, poreza na struju, poreza na kapital, poreza na osiguranje i mjenicu, dodatak (doplatak) na porez na dohodak tzv. dodatak solidarnosti (Solidaritätszuschlag) (čl. 105. st. 1. i čl. 106. st. 1.).

2) Savezna (federalna) jedinica - zemlja ima pravo na prihode od: poreza na nasljedstvo, poreza na promet nekretnina, poreza na pivo, poreza na kockarnice (čl. 106. st. 2.).

3) Općinama pripadaju prihodi od poreza na nekretnine (Grundsteuer) i poreza na poslovanje odnosno poslovni porez (Gewerbesteuer), kao i prihod od lokalnih poreza na potrošnju. Lokalni porezi na potrošnju obuhvaćaju, na primjer, porez na zabavu, porez na pse, porez na bezalkoholna pića i porez na drugi stan (kuću).

Međutim, najvažniji lokalni porez jest porez na poslovanje - poslovni porez koji predstavlja 43,2 \% ukupnog prihoda od poreza u općinama. Porez na nekretnine iznosi $14 \%$ ukupnog prihoda od poreza u općinama. ${ }^{22}$

Osim toga, čl. 106. st. 3. i čl. 106. st. 5. i 5a Temeljnog zakona Savezne Republike Njemačke predviđeno je da općine imaju pravo na udio (postotak) od prikupljenih prihoda od poreza na dohodak fizičkih osoba (koje imaju prebivalište ili uobičajeno boravište na području općine), kao i udio (postotak) od prikupljenih prihoda od poreza na promet. Odnosno prikupljeni prihodi od poreza na dohodak, poreza na

22 ECPRD Request no. 3159., Duties and financing of municipalities, 12. July 2016. 
dobit te poreza na dodanu vrijednost, zajednički se dijele između Savezne Republike Njemačke, saveznih (federalnih) jedinica - zemalja i lokalnih vlasti (zajednički porezi).

Zajednički porezi dijele se na sljedeći način: 1) $50 \%$ prihoda od poreza na dobit pripada Saveznoj Republici Njemačkoj, a $50 \%$ saveznim (federalnim) jedinicama - zemljama, 2) 42,5\% prihoda od poreza na dohodak pripada Saveznoj Republici Njemačkoj, 42,5\% saveznim (federalnim) jedinicama - zemljama, a 15 $\%$ općinama, 3) 49,4\% prihoda od poreza na dodanu vrijednost pripada Saveznoj Republici Njemačkoj, 48,3 \% saveznim (federalnim) jedinicama - zemljama, a 2,2 $\%$ općinama. ${ }^{23}$

Osim toga, postoji i sustav fiskalnog izravnanja kod općina, čime se stvara proračunska solidarnost među njima. ${ }^{24}$

Sustav fiskalnog izravnanja ima za cilj - kao što sama riječ kaže - ,izjednačenje“ prihoda koje unutar jedne savezne federalne (jedinice) - zemlje primaju lokalne vlasti. Sustav fiskalnog izjednačenja predviđa dva različita tipa odnosa: vertikalni odnos između savezne federalne (jedinice) - zemlje i općina i horizontalni odnos među lokalnim vlastima. Tehnički gledano, vertikalni je odnos onaj koji je važan, on određuje plaćanja savezne federalne (jedinice) - zemlje lokalnim vlastima. U biti, njime se pokušava izjednačiti prihode lokalnih vlasti u skladu s njihovim potrebama. Potrebe uzimaju u obzir različite poslove koje općina mora obaviti. Veći grad, primjerice, nudi više usluga nego druga područja. Gradovi i u manjem opsegu manje općine financiraju škole za posebne namjene, sportske ustanove, kulturu, javni prijevoz itd. Te razlike u javnim uslugama ovdje su uzete u obzir. Savezne federalne (jedinice) - zemlje imaju različite strategije: posebice veće savezne federalne (jedinice) - zemlje priznaju veće potrebe po stanovniku za veće gradove. Tako je, primjerice, u Sjevernoj Rajni Westfaliji, Bavarskoj i Donjoj Saskoj. Druge, posebice manje savezne federalne (jedinice) - zemlje, izabrale su druge načine. One osiguravaju novac za gradove koji obavljaju poslove središnje vlade. Nadalje, ovdje su uzeta u obzir „vlastita“ primanja lokalnih vlasti. Siromašne općine pritom dobivaju veću potporu nego bogate, ali cilj toga nije ujednačavanje standarda. ${ }^{25}$

\section{2. Kraljevina Španjolska}

Čl. 142. Ustava Kraljevine Španjolske propisano je da lokalne samouprave moraju imati dovoljno novčanih sredstava za obavljanje svojih funkcija. Kako bi to bilo ostvareno, jedinice lokalne samouprave ostvaruju prihode iz različitih izvora.

23 Bundesministerium der Finanzen, 2017., Finanzen § Steuern, Lehrerinfo 2017/2018., dostupno na: www.finanzen-und-steuern.de.

24 ECPRD Request no. 3159., Duties and financing of municipalities, 12. July 2016.

25 Podrobnije vidjeti u: V. J. Bibow i drugi, Fiskalische Austeritätspolitik und Lohnsenkung: Eine fatale, aber unverstandene Kombination als "Anpassungs - Programm» in den Eurokrisenländern, Arbeitskammer des Saarlandes, 2017., odnosno čl. 107. st. 2. Temeljnog zakona Savezne Republike Njemačke. 
U Kraljevini Španjolskoj jedinice lokalne samouprave financiraju se najvećim dijelom iz naplate lokalnih pristojbi i poreza, kao i od subvencija koje im dodjeljuju državne ili regionalne vlasti, u skladu s čl. 142. Ustava Kraljevine Španjolske. Osim toga, jedinice lokalne samouprave ubiru sredstva i od prihoda od nasljedstva, kao i iz drugih izvora, koja pritječu iz privatnog sektora. Također, jedinice lokalne samouprave mogu pozajmljivati novac u skladu sa zakonom propisanim uvjetima i ograničenjima. ${ }^{26}$

Financiranje jedinica lokalne samouprave regulirano je Kraljevskim zakonodavnim dekretom br. 2/2004. ${ }^{27}$ u kojem se taksativno navode svi dostupni izvori financiranja, i to:

1) vlastiti prihodi, između ostalih izvora reguliranim privatnim pravom,

2) prihodi od pristojbi, kategoriziranih kao tarife/pristojbe, posebni doprinosi i porezi, doplate od poreza koje ubiru samoupravne zajednice i druge lokalne ili regionalne vlasti,

3) udio u porezima koje ubire državna vlast i samoupravne zajednice,

4) razne vrste subvencija,

5) sredstva dodijeljena od strane državne vlasti u okviru fiskalnog izravnanja,

6) sredstva od kreditnih transakcija,

7) sredstva od kazni koje naplaćuje lokalna vlast,

8) drugi prihodi u skladu sa zakonom.

Opća shema koja se primjenjuje na općinsko oporezivanje, koje predstavlja glavni izvor financiranja, regulirana je trećim poglavljem Kraljevskog zakonodavnog dekreta br. 2/2004. Dekret navodi pet različitih poreza, od kojih su tri obvezna, a preostala dva mogu biti uvedena ukoliko lokalna vlast smatra da je to potrebno. Obvezni porezi su: porez na imovinu, porez na poslovanje i gospodarsku djelatnost, kao i porez na motorna vozila.

Dobrovoljni porezi su: porez na građevinske radove i porez na uvećanje vrijednosti izgrađenog (urbaniziranog) zemljišta.

\section{FINANCIRANJE JEDINICA LOKALNE I PODRUČNE (REGIONALNE) SAMOUPRAVE U REPUBLICI HRVATSKOJ}

Temeljni pravni propisi kojima se uređuju fiskalni odnosi između jedinica lokalne i područne (regionalne) samouprave i Republike Hrvatske su: Ustav Republike

26 ECPRD Request no. 3159., Duties and financing of municipalities, 12. July 2016.

27 Real Decreto Legislativo 2/2004., de 5 de marzo, por el que se aprueba el texto refundido de la Ley Reguladora de las Haciendas Locales. 
Hrvatske, ${ }^{28}$ Europska povelja o lokalnoj samoupravi ${ }^{29}$ Zakon o proračunu, ${ }^{30}$ Državni proračun Republike Hrvatske za 2018. godinu i projekcije za 2019. i 2020. godinu, ${ }^{31}$ Zakon o izvršavanju državnog proračuna Republike Hrvatske za 2018. godinu, ${ }^{32}$ Zakon o lokalnoj i područnoj (regionalnoj) samoupravi, ${ }^{33}$ Zakon o područjima županija, gradova i općina u Republici Hrvatskoj, ${ }^{34}$ Zakon o financiranju jedinica lokalne i područne (regionalne) samouprave, ${ }^{35}$ Zakon o lokalnim porezima, ${ }^{36}$ Zakon o porezu na promet nekretnina, ${ }^{37}$ Zakon o porezu na dohodak, ${ }^{38}$ Zakon o regionalnom razvoju Republike Hrvatske, ${ }^{39}$ Zakon o područjima posebne državne skrbi, ${ }^{40}$ Zakon o komunalnom gospodarstvu, ${ }^{41}$ Zakon o koncesijama, ${ }^{42}$ Uredba o indeksu razvijenosti, ${ }^{43}$ Uredba o načinu financiranja decentraliziranih funkcija te izračuna iznosa pomoći izravnanja za decentralizirane funkcije jedinica lokalne i područne (regionalne) samouprave za 2018. godinu, ${ }^{44}$ Odluka o razvrstavanju jedinica lokalne i područne (regionalne) samouprave prema stupnju razvijenosti, ${ }^{45}$ Odluke o gradskim i općinskim porezima i drugi pravni propisi. ${ }^{46}$

28 Narodne novine, br. 56/90, 135/97, 08/98, 113/00, 124/00, 28/01, 41/01, 55/01, 76/10, 85/10 i $05 / 14$.

29 Europsku povelju o lokalnoj samoupravi potpisale su države članice Europskog vijeća 15. listopada 1985. godine u Strasbourgu. Povelja je ostavila mogućnost naknadnog pristupa drugim državama, a to pravo iskoristila je Republika Hrvatska, pa je nakon što je 6. studenoga 1996. godine postala punopravna članica Vijeća Europe, dana 19. rujna 1997. godine donijela Zakon o potvrđivanju Europske povelje o lokalnoj samoupravi. Tim zakonom Povelja je postala dio pravnog poretka Republike Hrvatske - Narodne novine - Međunarodni ugovori, br. 14/97, 2/07, 4/08 i 5/08.

30 Narodne novine, br. 87/08, 136/12 i 15/15.

31 Narodne novine, 124/17.

32 Narodne novine, br. $124 / 17$

33 Narodne novine, br. 33/01, 60/01, 129/05, 109/07, 125/08, 36/09, 150/11, 144/12, 19/13, 137/15 i $123 / 17$.

34 Narodne novine, br. 86/06, 125/06 - ispravak, 16/07 - ispravak, 46/10 - ispravak, 145/10, 37/13, 44/13, 45/13, 110/15, Odluka USRH - 95/08.

35 Narodne novine, br. 127/17.

36 Narodne novine, br. 115/16 i 101/17.

37 Narodne novine, br. 115/16

38 Narodne novine, br. 115/16.

39 Narodne novine, br. 147/14 i 123/17.

40 Narodne novine, br. 86/08, 57/11, 51/13, 148/13, 76/14, 147/14 i 18/15.

41 Narodne novine, br. $68 / 18$.

42 Narodne novine, br. 69/17.

43 Narodne novine, br. 131/17.

44 Narodne novine, br. $7 / 2018$.

45 Narodne novine, br. 132/17.

46 Na primjer Pravilnik o uvjetima, opsegu i naknadi za obavljanje poslova utvrđivanja, evidentiranja, nadzora, naplate i ovrhe radi naplate poreza jedinica lokalne i područne (regionalne) samouprave, Narodne novine br. 1/17., Pravilnik o načinu ostvarivanja porezne olakšice za obavljanje djelatnosti na području grada Vukovara i na potpomognutim područjima, Narodne novine, br. 18/08., Pravilnik o proračunskim klasifikacijama, Narodne novine, br. 26/10 i 120/13., Pravilnik o proračunskom računovodstvu i računskom planu, Narodne novine, br. 124/12, 115/15, 87/16 i 3/18. i slično. 
Dr. sc. Zoran Šinković: Financiranje jedinica lokalne i područne (regionalne)...

Zbornik radova Pravnog fakulteta u Splitu, god. 56, 1/2019., str. 223.- 250.

Osnovna zamisao Europske povelje o lokalnoj samoupravi temelji se na tome da Europa mora biti izgrađena na načelima demokracije i decentralizacije vlasti, gdje lokalne jedinice predstavljaju jedan od glavnih temelja jer u njima građani imaju mogućnost ostvarivanja neposrednog prava upravljanja javnim poslovima.

Ustavne odredbe o lokalnim jedinicama u potpunosti su u skladu s Europskom poveljom o lokalnoj samoupravi pa tako Ustav Republike Hrvatske izrijekom daje građanima pravo neposrednog sudjelovanja u lokalnim poslovima. To pravo u Republici Hrvatskoj imaju i građani Europske unije u skladu sa zakonom i pravnom stečevinom Europske unije (čl. 128. st. 3. i 4. Ustava Republike Hrvatske). Nadalje, Ustav Republike Hrvatske prihvaća načelo samoorganizacije - jedinice lokalne i područne (regionalne) samouprave imaju pravo u okviru zakona svojim statutima samostalno urediti unutarnje ustrojstvo i djelokrug svojih tijela te ih prilagoditi lokalnim potrebama i mogućnostima (čl. 129.b. Ustava Republike Hrvatske).

Da bi se mogla ostvariti gore proklamirana načela, lokalnim tijelima mora se omogućiti određena razina financijske autonomije, stoga Ustav Republike Hrvatske propisuje način financiranja lokalnih jedinica, što je u skladu s odredbama Europske povelje o lokalnoj samoupravi. ${ }^{47}$ Tako je čl. 131. st. 1. Ustava Republike Hrvatske propisano da jedinice lokalne i područne (regionalne) samouprave imaju pravo na vlastite prihode kojima slobodno raspolažu u obavljanju poslova iz svojeg djelokruga. Prihodi jedinica lokalne i područne (regionalne) samouprave moraju biti razmjerni njihovim ovlastima predviđenima Ustavom i zakonom (čl. 131. st. 2. Ustava Republike Hrvatske). Također je Republika Hrvatska dužna pomagati financijski slabije jedinice lokalne samouprave u skladu sa zakonom (čl. 131. st. 3. Ustava Republike Hrvatske).

Ipak treba istaknuti da je Europska povelja o lokalnoj samoupravi fundamentalan dokument Europskog vijeća o financijskoj decentralizaciji i demokratizaciji država koje su prihvatile Povelju, ali konačni stupanj decentralizacije i način financiranja lokalnih razina vlasti ipak u cijelosti ovisi o političkim tijelima središnje države i o njihovim političkim i gospodarskim interesima. ${ }^{48}$

47 Čl. 9. Povelje o lokalnoj samoupravi glasi: „1. Lokalne će jedinice imati, u okviru državne gospodarske politike, pravo na odgovarajuće svoje prihode kojima će slobodno raspolagati u obavljanju svojih ovlasti. 2. Prihodi lokalnih jedinica moraju biti razmjerni njihovim ovlastima predviđenim ustavom i zakonom. 3. Najmanje dio prihoda lokalnih jedinica mora proizlaziti iz lokalnih poreza i naknada čije stope, granicama utvrđenim zakonom, same određuju. 4. Sustavi financiranja prihoda lokalnih jedinica moraju biti dovoljno raznoliki i evolutivni kako bi mogli slijediti, koliko je to praktički moguće, promjene stvarnih troškova obavljanja lokalnih vlasti. 5. Zaštita financijski slabijih lokalnih jedinica traži prihvaćanje odgovarajućih postupaka ili mjera financijskog ujednačavanja u cilju ispravljanja učinaka nejednake diobe mogućih izvora financiranja, odnosno financijskog opterećenja što ga moraju podnositi. Takvim postupcima ili mjerama ne smije se sužavati slobodno odlučivanje lokalnih jedinica o pitanjima koja su u njihovom djelokrugu. 6. Od lokalnih će se jedinica, na odgovarajući način, tražiti mišljenja o tome kako će im se dodjeljivati preraspoređeni izvori financiranja. 7. Koliko je to moguće, subvencije lokalnim jedinicama neće biti namijenjene financiranju specifičnih projekata. Dodjelom tih sredstava neće se ugrožavati temeljna sloboda politike odlučivanja lokalnih jedinica u području njihovih vlastitih nadležnosti. 8. Kako bi se financirali njihovi troškovi investiranja, lokalne jedinice moraju imati, u skladu sa zakonom, pristup nacionalnom tržištu kapitala."

48 D. Špoljarić i drugi, „Normativna osnova financiranja lokalnih razina u Republici Hrvatskoj“, FIP - Financije i pravo, god. 5., br. 1/2017., Visoko učilište Effectus - Visoka škola za financije i pravo, Zagreb, 2017., str. 64-65. 


\section{1. Proračun i izvori financiranja}

Proračun je sustavno sređen i u osnovi obvezan prijedlog javnih rashoda i procjena javnih prihoda kojima će se ti rashodi podmirivati za jedno buduće utvrđeno plansko razdoblje, uvažavajući različite aspekte pravne, političke, financijske, ekonomske, socijalne, administrativne i druge..$^{49}$

Osnovni instrument financiranja javnih rashoda u gotovo svim suvremenim državama jest državni proračun, odnosno lokalni proračuni. U Republici Hrvatskoj to je državni proračun Republike Hrvatske ${ }^{50}$ odnosno proračuni jedinica lokalne i područne (regionalne) samouprave ${ }^{51}$ koji se donose svake proračunske godine

49 Postoji pet teorija o pravnoj prirodi proračuna:

1. Za neke teoretičare proračun nije nikada zakon nego upravni akt. Kako se porezni prihodi ubiru na osnovi zakona o porezima, a ne na osnovi proračuna, proračun se kao plan prihoda ne može tretirati kao zakon kojim se uvodi obveza plaćanja poreza.

2. Proračun je dijelom upravni akt, a dijelom zakon. Prema nekim teoretičarima, u državama u kojima se porezna obveza utvrđuje jednogodišnje, u kojima se porezni prihodi mogu ubirati samo onda ako je i kada je parlament odobrio proračun, susrećemo se s proračunom koji u tom dijelu ima karakter zakona. U dijelu u kojem se utvrđuju rashodi u proračunu, proračun ima karakter upravnog akta.

3. Ima teoretičara koji zastupaju stajalište po kojem je proračun samo u jednom dijelu zakon i to samo u formalnom smislu. Proračun je zakon samo po svojoj formi, po svom vanjskom obliku, po načinu donošenja, ali on to nije s obzirom na svoj sadržaj jer ne sadrži obvezna pravna pravila. Po svom sadržaju proračun je upravni akt.

4. Za neke teoretičare proračun je zakon i u formalnom i u materijalnom smislu. Po njima proračun je zakon i to zakon kako s formalnog tako i sa sadržajnog stajališta. Proračun ima karakter pravog zakona. Proračun omogućuje ,da oni pojedinci koji rade kao državni organi, mogu u ime i za državu sklapati pravovaljane poslove i vršiti radnje unutar područja i granica samog zakona“. Taj karakter proračuna proistječe iz činjenice da je proračun zakon, a ne upravni akt.

5. Neki teoretičari smatraju da je proračun pravni posao između vlade i parlamenta, drugim riječima proračun je u formu zakona zaodjenut pravni posao, koji se svake godine sklapa između parlamenta $\mathrm{i}$ vlade, a koji sadržava parlamentarno odobrenje za vršenje prihoda koji su u njemu sadržani. Podrobnije vidjeti u: Bo. Jelčić, V. Poglavlje „'Javni rashodi’ Državni proračun (budžet)“ u: Bo. Jelčić i drugi, Financijsko pravo i financijska znanost, Narodne novine, Zagreb, 2002., str. 613-615.

50 Hrvatski sabor donosi državni proračun (čl. 81. Ustava Republike Hrvatske). Vlada Republike Hrvatske predlaže državni proračun i završni račun (čl. 110. Ustava Republike Hrvatske). Predsjednik Republike, na prijedlog Vlade i uz supotpis predsjednika Vlade, a nakon savjetovanja s predstavnicima klubova zastupnika parlamentarnih stranaka, može raspustiti Hrvatski sabor ako na zahtjev Vlade da se izglasa povjerenje, Hrvatski sabor Vladi izglasa nepovjerenje ili u roku od 120 dana od dana predlaganja ne donese državni proračun (čl. 104. Ustava Republike Hrvatske).

51 Temeljni financijski akt jedinice lokalne i područne (regionalne) samouprave jest proračun. Općinski načelnik, gradonačelnik, odnosno župan, kao jedini ovlašteni predlagatelj, dužan je utvrditi prijedlog proračuna i podnijeti ga predstavničkom tijelu na donošenje $u$ roku utvrđenom posebnim zakonom. Proračun donosi predstavničko tijelo jedinice lokalne i područne (regionalne) samouprave u skladu s posebnim zakonom (čl. 69. st. 1. 2. i 3. Zakona o lokalnoj i područnoj (regionalnoj) samoupravi).

Ako općinski načelnik, gradonačelnik, odnosno župan ne predloži proračun predstavničkom tijelu ili povuče prijedlog prije glasovanja o proračunu u cjelini te ne predloži novi prijedlog proračuna u roku koji omogućuje njegovo donošenje, Vlada Republike Hrvatske će na prijedlog središnjeg tijela državne uprave nadležnog za lokalnu i područnu (regionalnu) samoupravu razriješiti općinskog načelnika, gradonačelnika, odnosno župana i njihova zamjenika koji je izabran zajedno s njima (čl. 69.a st. 1. Zakona o lokalnoj i područnoj (regionalnoj) samoupravi).

U slučaju iz st. 1. ovoga članka Vlada Republike Hrvatske imenovat će povjerenika Vlade Republike Hrvatske za obavljanje poslova iz nadležnosti općinskog načelnika, gradonačelnika, odnosno župana 
Dr. sc. Zoran Šinković: Financiranje jedinica lokalne i područne (regionalne)...

Zbornik radova Pravnog fakulteta u Splitu, god. 56, 1/2019., str. 223.- 250.

i raspisati prijevremene izbore za općinskog načelnika, gradonačelnika, odnosno župana sukladno posebnom zakonu (čl. 69.a st. 2. Zakona o lokalnoj i područnoj (regionalnoj) samoupravi).

Novoizabrani općinski načelnik, gradonačelnik, odnosno župan dužan je predložiti predstavničkom tijelu proračun u roku od 45 dana od dana stupanja na dužnost (čl. 69.a st. 3. Zakona o lokalnoj i područnoj (regionalnoj) samoupravi).

Predstavničko tijelo mora donijeti proračun iz st. 3. ovog članka u roku od 45 dana od dana kada ga je općinski načelnik, gradonačelnik, odnosno župan predložio predstavničkom tijelu (čl. 69.a st. 4. Zakona o lokalnoj i područnoj (regionalnoj) samoupravi).

Rješenje Vlade Republike Hrvatske o razrješenju općinskog načelnika, gradonačelnika, odnosno župana iz st. 1. ovoga članka stupa na snagu danom objave u „Narodnim novinama“ (čl. 69.a st. 5. Zakona o lokalnoj i područnoj (regionalnoj) samoupravi).

Protiv rješenja Vlade Republike Hrvatske iz st. 5. ovoga članka razriješeni općinski načelnik, gradonačelnik, odnosno župan može podnijeti tužbu Visokom upravnom sudu Republike Hrvatske u roku od 8 dana od dana objave rješenja (čl. 69.a st. 6. Zakona o lokalnoj i područnoj (regionalnoj) samoupravi).

Postupak rješavanja o tužbi protiv rješenja Vlade Republike Hrvatske je hitan (čl. 69.a st. 7. Zakona o lokalnoj i područnoj (regionalnoj) samoupravi).

Visoki upravni sud Republike Hrvatske odlučit će o tužbi u roku od 30 dana od dana primitka tužbe te svoju odluku bez odgađanja dostaviti Vladi Republike Hrvatske i razriješenom općinskom načelniku, gradonačelniku, odnosno županu (čl. 69.a st. 8. Zakona o lokalnoj i područnoj (regionalnoj) samoupravi).

Odluka Visokog upravnog suda Republike Hrvatske objavljuje se u „Narodnim novinama“ (čl. 69.a st. 9. Zakona o lokalnoj i područnoj (regionalnoj) samoupravi).

Ako je tužba odbačena ili odbijena, Vlada Republike Hrvatske će raspisati prijevremene izbore za općinskog načelnika, gradonačelnika, odnosno župana u roku od 90 dana od dana objave odluke Visokog upravnog suda Republike Hrvatske u „Narodnim novinama“ (čl. 69.a st. 10. Zakona o lokalnoj i područnoj (regionalnoj) samoupravi).

Ako predstavničko tijelo ne donese proračun prije početka proračunske godine, privremeno se, a najdulje za prva tri mjeseca proračunske godine, na osnovi odluke o privremenom financiranju, nastavlja financiranje poslova, funkcija i programa tijela jedinica lokalne i područne (regionalne) samouprave i drugih proračunskih i izvanproračunskih korisnika u skladu s posebnim zakonom (čl. 70. st. 1. Zakona o lokalnoj i područnoj (regionalnoj) samoupravi).

Odluku o privremenom financiranju iz st. 1. ovoga članka donosi do 31. prosinca predstavničko tijelo u skladu s posebnim zakonom na prijedlog općinskog načelnika, gradonačelnika, odnosno župana ili povjerenika Vlade Republike Hrvatske (čl. 70. st. 2. Zakona o lokalnoj i područnoj (regionalnoj) samoupravi).

U slučaju kada je raspušteno samo predstavničko tijelo, a općinski načelnik, gradonačelnik, odnosno župan nije razriješen, do imenovanja povjerenika Vlade Republike Hrvatske, financiranje se obavlja izvršavanjem redovnih i nužnih rashoda i izdataka temeljem odluke o financiranju nužnih rashoda i izdataka koju donosi općinski načelnik, gradonačelnik, odnosno župan (čl. 70. st. 3. Zakona o lokalnoj i područnoj (regionalnoj) samoupravi).

Po imenovanju povjerenika Vlade Republike Hrvatske, općinski načelnik, gradonačelnik, odnosno župan predlaže povjereniku novu odluku o financiranju nužnih rashoda i izdataka u koju su uključeni ostvareni prihodi i primici te izvršeni rashodi i izdaci u vremenu do dolaska povjerenika (čl. 70. st. 4. Zakona o lokalnoj i područnoj (regionalnoj) samoupravi).

Ako se do 31. ožujka ne donese proračun, povjerenik donosi odluku o financiranju nužnih rashoda i izdataka za razdoblje do donošenja proračuna (čl. 70. st. 5. Zakona o lokalnoj i područnoj (regionalnoj) samoupravi).

Odluka o financiranju nužnih rashoda i izdataka iz st. 3. 4. i 5. ovoga članka sadržajno odgovara odluci o privremenom financiranju propisanoj posebnim zakonom, ali razmjerno razdoblju za koje se donosi (čl. 70. st. 6. Zakona o lokalnoj i područnoj (regionalnoj) samoupravi).

Ukupno materijalno i financijsko poslovanje općine, grada i županije nadzire njihovo predstavničko tijelo (čl. 71. Zakona o lokalnoj i područnoj (regionalnoj) samoupravi). 
kako bi Republika Hrvatska odnosno županije, gradovi i općine ${ }^{52}$ mogli obavljati poslove iz svoje nadležnosti odnosno na temelju ustava, zakona i drugih propisa zadovoljavati (financirati) i podmirivati određene javne rashode. ${ }^{53}$ Drugim riječima, decentralizacija upućuje na proces redistribucije ovlasti, političkih, upravnih i fiskalnih, na korist lokalnih razina vlasti. Decentralizacija se može promatrati i kao usporedni proces jačanja odgovornosti lokalnih jedinica za ukupnu kakvoću i ,ponudu“ javnih usluga na lokalnom području. Na temelju takve tendencije leži koncepcija lokalnoga napretka označena složenicom endogeni razvoj. Zamisao o endogenom razvoju oslanja se na relativno jednostavne premise. Tri „markantnije“ jesu: a) transformacija društveno-ekonomskoga sklopa na određenom području može se izazvati poticajima ,iznutra“, poticajima „odozdo“, b) sposobnost reagiranja lokalne zajednice na vanjske izazove središnji je pokazatelj razvojne sposobnosti i otpornosti, c) treba uvoditi specifične oblike društvene regulative na lokalnoj razini, kako bi se izašlo ususret razvoju „odozdo“. ${ }^{54}$

Stoga je čl. 68. Zakona o lokalnoj i područnoj (regionalnoj) samoupravi propisano da jedinica lokalne samouprave i jedinica područne (regionalne) samouprave ima prihode kojima u okviru svoga samoupravnog djelokruga slobodno raspolaže. Prihodi jedinice lokalne samouprave i jedinice područne (regionalne) samouprave moraju biti razmjerni s poslovima koje obavljaju njihova tijela u skladu sa zakonom. Prihodi jedinice lokalne, odnosno područne (regionalne) samouprave su: 1. općinski, gradski, odnosno županijski porezi, prirez, naknade, doprinosi i pristojbe, 2. prihodi od stvari u njezinu vlasništvu i imovinskih prava, 3. prihodi od trgovačkih društava i drugih pravnih osoba u njezinu vlasništvu, odnosno u kojima ima udio ili dionice, 4. prihodi od naknada za koncesije, 5. novčane kazne i oduzeta imovinska korist za prekršaje koje sama propiše u skladu sa zakonom, 6. udio u zajedničkom porezu, 7. sredstva pomoći Republike Hrvatske predviđena u državnom proračunu, 8. drugi prihodi određeni zakonom.

Ministarstvo financija, odnosno drugo zakonom određeno tijelo, nadzire zakonitost materijalnog i financijskog poslovanja jedinica lokalne samouprave i jedinica područne (regionalne) samouprave (čl. 72. Zakona o lokalnoj i područnoj (regionalnoj) samoupravi).

52 U Republici Hrvatskoj ustrojeno je ukupno 555 jedinica lokalne samouprave, i to 428 općina i 127 gradova te 20 jedinica područne (regionalne) samouprave, odnosno županija. Grad Zagreb, kao glavni grad Republike Hrvatske, ima poseban status grada i županije, tako da je u Republici Hrvatskoj sveukupno 576 jedinica lokalne i područne (regionalne) samouprave. Navedeno prema: https://uprava. gov.hr/o-ministarstvu/ustrojstvo/uprava-za-politicki-sustav-i-organizaciju-uprave/lokalna-i-podrucnaregionalna-samouprava/popis-zupanija-gradova-i-opcina/846 i Zakon o područjima županija, gradova i općina u Republici Hrvatskoj.

53 Hrvatska lokalna samouprava organizirana je na dvije razine. Prvu razinu predstavljaju jedinice lokalne samouprave, gradovi i općine, koje su organizirane kao politipične jedinice lokalne samouprave. Takvi su tipovi lokalne samouprave prije svega odgovorni za komunalne poslove i urbano planiranje. Na drugoj razini nalaze se županije koje su odgovorne za više decentraliziranih javnih službi na lokalnoj razini, prije svega za zdravstvenu skrb, osnovno školstvo i druge lokalne obrazovne institucije, kao i za koordinaciju između jedinica lokalne samouprave na vlastitom području. Podrobnije vidjeti u: M. Klarić, „Problems and developments in the Croatian local self-government", Zbornik radova Pravnog fakulteta $u$ Splitu, god. 54., br. 4/2017., Pravni fakultet Sveučilišta u Splitu, Split, 2017., str. 807-823.

54 T. Rogić Lugarić, „Normativna decentralizacija u Hrvatskoj i njezine granice“, Društvena istraživanja, god. 14., br. 6/2005., Institut društvenih znanosti Ivo Pilar, Zagreb, 2005., str. 1188. 
Iz gore navedenoga zaključuje se da Zakon o lokalnoj i područnoj (regionalnoj) samoupravi navodi prihode (izvore) iz kojih se financiraju jedinice lokalne i područne (regionalne) samouprave, dok su prihodi (izvori) financiranja istih detaljno razrađeni u Zakonu o lokalnim porezima i Zakonu o financiranju jedinica lokalne i područne (regionalne) samouprave.

Jedinice lokalne i područne (regionalne) samouprave stječu prihode iz: 1) vlastitih izvora, 2) zajedničkog poreza, 3) zajedničkih prihoda od naknada za koncesije, 4) pomoći - fiskalno izravnanje, 5) zaduživanja.

\subsubsection{Vlastiti izvori financiranja jedinica područne (regionalne) samouprave}

Vlastiti izvori županija su:

1) prihodi od vlastite imovine (na primjer najam, zakup, naknade za koncesije, prodaja nefinancijske imovine, prihodi od trgovačkih društava i drugih pravnih osoba u njezinu vlasništvu, odnosno u kojima ima udio ili dionice),

2) županijski porezi (porez na nasljedstva i darove, porez na cestovna motorna vozila, porez na plovila, porez na automate za zabavne igre), ${ }^{55}$

3) prihodi od administrativnih (upravnih) pristojbi u skladu s posebnim zakonom,

4) novčane kazne i oduzeta imovinska korist za prekršaje, koje sami propišu,

5) drugi prihodi utvrđeni posebnim zakonom.

\subsubsection{Vlastiti izvori financiranja jedinica lokalne samouprave}

Vlastiti izvori gradova i općina su:

1) prihodi od vlastite imovine (na primjer najam, zakup, naknade za koncesije, prodaja nefinancijske imovine, prihodi od trgovačkih društava i drugih pravnih osoba u njihovu vlasništvu, odnosno u kojima ima udio ili dionice),

2) gradski odnosno općinski porezi (prirez porezu na dohodak, porez na potrošnju, porez na kuće za odmor, porez na korištenje javnih površina, porez na promet nekretnina), ${ }^{56}$

3) novčane kazne i oduzeta imovinska korist za prekršaje, koje sami propišu,

4) prihodi od administrativnih (upravnih) pristojbi u skladu s posebnim zakonom,

5) prihodi od boravišnih pristojbi u skladu s posebnim zakonom,

6) prihodi od komunalnih naknada, komunalnih doprinosa i druge naknade utvrđene posebnim zakonom,

7) naknade za uporabu javnih, općinskih ili gradskih površina,

8) drugi prihodi utvrđeni posebnim zakonom.

55 Podrobnije vidjeti čl. 3.-19. i čl. 45.-48. Zakona o lokalnim porezima.

56 Podrobnije vidjeti čl. 20.-29. i čl. 49. Zakona o lokalnim porezima i čl. 1.-39. Zakona o porezu na promet nekretnina. 


\subsubsection{Zajednički porez}

Prema čl. 5. st. 1. Zakona o financiranju jedinica lokalne i područne (regionalne) samouprave, porez na dohodak jest zajednički porez čiji se prihod dijeli između općina, gradova i županija.

Prema čl. 5. st. 2. Zakona o financiranju jedinica lokalne i područne (regionalne) samouprave, prihod od poreza na dohodak raspodjeljuje se na:

toč. 1. udio općine, odnosno grada $60 \%$,

toč. 2. udio županije $17 \%$,

toč. 3. udio za decentralizirane funkcije $6 \%$,

toč. 4. udio za fiskalno izravnanje $17 \%$.

Prema čl. 5. st. 3. Zakona o financiranju jedinica lokalne i područne (regionalne) samouprave općina, grad, županija i Grad Zagreb, koji prema posebnim propisima financiraju decentralizirane funkcije, raspodjeljuju udio za decentralizirane funkcije iz st. 2. toč. 3. ovoga članka na sljedeći način:

- za osnovno školstvo $1,9 \%$,

- $\quad$ za srednje školstvo $1,3 \%$,

- $\quad$ za socijalnu skrb $0,8 \%$, i to $0,2 \%$ za centre za socijalnu skrb i $0,6 \%$ za domove za starije i nemoćne osobe,

- za zdravstvo $1,0 \%$,

- za vatrogastvo - javne vatrogasne postrojbe 1,0\%.57 58

Drugim riječima čl. 10. st. 1. Zakona o financiranju jedinica lokalne i područne (regionalne) samouprave propisano je da Vlada Republike Hrvatske u Odlukama o minimalnim financijskim standardima utvrđuje minimalan iznos sredstava koja je potrebno osigurati za pokriće rashoda za decentralizirane funkcije osnovnog i srednjeg školstva, socijalne skrbi, zdravstva i vatrogastva.

Prema čl. 10. st. 2. Zakona o financiranju jedinica lokalne i područne (regionalne) sredstva za pokriće rashoda za decentralizirane funkcije osnovnog i srednjeg školstva, socijalne skrbi, zdravstva i vatrogastva, koje se prema posebnom zakonu prenose na jedinice lokalne i područne (regionalne) samouprave, osiguravaju se iz udjela za decentralizirane funkcije iz čl. 5. st. 2. toč. 3. ovoga Zakona.

Prema čl. 10. st. 5. Vlada Republike Hrvatske Uredbom o načinu financiranja decentraliziranih funkcija te izračuna iznosa pomoći izravnanja za decentralizirane funkcije jedinica lokalne i područne (regionalne) samouprave za 2018. godinu

57 Iznimno od čl. 5. st. 3. Zakona o financiranju jedinica lokalne i područne (regionalne) samouprave udio za decentraliziranu funkciju koju jedinice lokalne i područne (regionalne) samouprave nisu preuzele, a imaju zakonsku mogućnost, raspodjeljuje se u jednakim dijelovima na ostale preuzete decentralizirane funkcije na području jedinice lokalne, odnosno područne (regionalne) samouprave (čl. 6. st. 1. Zakona o financiranju jedinica lokalne i područne (regionalne) samouprave.

58 Prema čl. 5. st. 4. Zakona o financiranju jedinica lokalne i područne (regionalne) samouprave za troškove obavljanja poslova utvrđivanja, evidentiranja, naplate, nadzora i ovrhe poreza na dohodak Ministarstvu financija Poreznoj upravi pripada naknada $1 \%$ od ukupno naplaćenih prihoda. 
Dr. sc. Zoran Šinković: Financiranje jedinica lokalne i područne (regionalne)...

Zbornik radova Pravnog fakulteta u Splitu, god. 56, 1/2019., str. 223.- 250.

utvrđuje način financiranja decentraliziranih funkcija i način izračuna pomoći izravnanja za decentralizirane funkcije. Na temelju navedene Uredbe, Republika Hrvatska isplatila je za decentralizirane funkcije na razini svih županija iznos od 2.286.537.660 kuna, prvenstveno onim županijama, gradovima i općinama koji su ostvarili manje sredstava od iznosa utvrđenog Odlukama Vlade Republike Hrvatske o minimalnim financijskim standardima za pokriće rashoda za decentralizirane funkcije osnovnog i srednjeg školstva, socijalne skrbi, zdravstva i vatrogastva. Navedena novčana sredstva osiguravaju se u državnom proračunu Republike Hrvatske na razdjelima ministarstava nadležnih za osnovno i srednje školstvo, socijalnu skrb, zdravstvo i vatrogastvo. ${ }^{59} 60$

\subsubsection{Zajednički prihodi od naknada za koncesije}

Prema čl. 3. st. 5. Zakona o financiranju jedinica lokalne i područne (regionalne) samouprave zajednički prihodi države, općine i grada jesu i prihodi od ugovorenih godišnjih naknada za koncesije, prema Zakonu o koncesijama i to:

1. za crpljenje mineralnih, geotermalnih i prirodnih izvorskih voda,

2. za zahvaćanje voda za javnu vodoopskrbu.

Prema čl. 3. st. 6. Zakona o financiranju jedinica lokalne i područne (regionalne) samouprave prihodi iz st. 5. ovoga članka dijele se između države, općine i grada

59 Čl. 11. st. 1. Zakona o financiranju jedinica lokalne i područne (regionalne) samouprave propisuje ako jedinice lokalne i područne (regionalne) samouprave koje financiraju decentralizirane funkcije ostvare više sredstava iz udjela iz čl. 5. st. 2. toč. 3. ovoga Zakona nego je to utvrđeno minimalnim financijskim standardima utvrđenima u skladu s čl. 10. st. 1. ovoga Zakona, višak sredstava mogu koristiti za financiranje decentraliziranih funkcija koje su preuzele.

Čl. 11. st. 2. Zakona o financiranju jedinica lokalne i područne (regionalne) samouprave propisuje ako jedinice lokalne i područne (regionalne) samouprave koje financiraju decentralizirane funkcije ostvare više sredstava iz pomoći izravnanja nego je to utvrđeno minimalnim financijskim standardima utvrđenima u skladu s čl. 10. st. 1. ovoga Zakona, višak sredstava dužne su uplatiti na račun državnog proračuna Republike Hrvatske u roku utvrđenom u Uredbi iz čl. 10. st. 5. ovoga Zakona.

Čl. 11. st. 3. Zakona o financiranju jedinica lokalne i područne (regionalne) samouprave propisuje da je višak sredstava iz st. 2. ovoga članka prihod državnog proračuna Republike Hrvatske.

Čl. 11. st. 4. Zakona o financiranju jedinica lokalne i područne (regionalne) samouprave propisuje da je jedinica lokalne i područne (regionalne) samouprave odgovorna za preuzete decentralizirane funkcije dužna sredstva za pokriće rashoda za decentralizirane funkcije raspodijeliti svakoj ustanovi sukladno odlukama o minimalnim financijskim standardima iz čl. 10. st. 1. ovoga Zakona.

60 U istraživanju stavova lokalnih jedinica o decentralizaciji sudjelovalo je $43 \%$ općina i gradova u Republici Hrvatskoj. Prikupljeni podaci o provedenoj decentralizaciji u Republici Hrvatskoj pokazuju da većina lokalnih jedinica nije preuzela tzv. decentralizirane funkcije. Više od pola jedinica koje su odgovorile na upitnik (njih $58 \%$ ) do danas nije uopće preuzelo decentralizirane funkcije niti u jednom upravnom području u kojem je taj proces pokrenut 2001. godine. Samo $1 \%$ ispitanih jedinica preuzeo je decentralizirane funkcije u zdravstvu, $5 \%$ u socijalnoj skrbi, $8 \%$ u obrazovanju, dok ih je gotovo trećina $(28 \%)$ preuzela decentralizirane funkcije u upravnome području vatrogastva. Na razini ukupnoga broja svih općina, gradova i županija u Republici Hrvatskoj decentralizirane funkcije preuzelo je samo $6 \%$ jedinica lokalne i područne (regionalne) samouprave. Riječ je uglavnom o županijama i velikim gradovima te gradovima sjedištima županija. Navedeno prema: V. Đulabić, Lokalna samouprava i decentralizacija u Hrvatskoj, Rezultati istraživanja i preporuke za poboljšanje politike decentralizacije, Friedrich-EbertStiftung, Zagreb, 2018., str. 8. 
Dr. sc. Zoran Šinković: Financiranje jedinica lokalne i područne (regionalne)...

Zbornik radova Pravnog fakulteta u Splitu, god. 56, 1/2019., str. 223.- 250.

na čijem se području ostvaruje pravo crpljenja mineralnih, geotermalnih i prirodnih izvorskih voda te zahvaćanje voda za javnu vodoopskrbu tako da:

1. udio općine i grada u prihodu od naknada za koncesiju za crpljenje mineralnih, geotermalnih i prirodnih izvorskih voda iznosi $50 \%$, a države $50 \%$,

2. udio općine i grada u prihodu od naknada za koncesiju za zahvaćanje voda za javnu vodoopskrbu iznosi $30 \%$, a države $70 \%$.

\subsubsection{Pomoći - fiskalno izravnanje}

Osim jednog vida pomoći za decentralizirane funkcije, županije, gradovi i općine imaju pravo i na druge vidove pomoći na primjer kompenzacijske mjere,${ }^{61}$ pomoći od međunarodnih organizacija, pomoći temeljem prijenosa sredstava Europske unije, pomoći proračunskim korisnicima iz proračuna koji im nije nadležan, pomoći od ostalih subjekata unutar općeg proračuna odnosno raspodjela sredstava putem fiskalnog izravnanja.

U skladu s gore navedenim čl. 8. Zakona o financiranju jedinica lokalne i područne (regionalne) samouprave reguliran je institut raspodjele sredstava fiskalnog izravnanja. Prema čl. 8. st. 1. Zakona o financiranju jedinica lokalne i područne (regionalne) samouprave općine, gradovi i županije čiji je kapacitet ostvarenih poreznih prihoda manji od referentne vrijednosti kapaciteta ostvarenih poreznih prihoda ostvaruju pravo na sredstva fiskalnog izravnanja. ${ }^{62}$ Referentna vrijednost

61 Dana 15. siječnja 2018. godine isplaćena je pomoć (kompenzacijske mjere) u iznosu od 706 milijuna kuna jedinicama lokalne i područne (regionalne) samouprave planirana u Državnom proračunu Republike Hrvatske za 2018. godinu, na razdjelu Ministarstva financija, temeljem čl. 52. Zakona o izvršavanju Državnog proračuna Republike Hrvatske za 2017. godinu. Navedeno prema: http://www. mfin.hr/hr/lokalna-samouprava.

62 Čl. 8. st. 2. Zakona o financiranju jedinica lokalne i područne (regionalne) samouprave propisuje da kapacitet ostvarenih poreznih prihoda iz st 1. ovoga članka općine, odnosno grada jest petogodišnji prosjek ukupnih prihoda od poreza na dohodak ostvarenih na području općine, odnosno grada te prihoda od prireza koji bi općina, odnosno grad ostvario uvođenjem najviše propisane stope prireza, po glavi stanovnika pojedine općine, odnosno grada.

Čl. 8. st. 3. Zakona o financiranju jedinica lokalne i područne (regionalne) samouprave propisuje da referentna vrijednost kapaciteta ostvarenih poreznih prihoda iz st. 1. ovoga članka za općine jest petogodišnji prosjek ukupnih prihoda od poreza na dohodak ostvarenih na području svih općina te prihoda od prireza koje bi općine ostvarile uvođenjem najviše propisane stope prireza, po glavi stanovnika svih općina, koji se uvećava za $50 \%$ tako dobivene vrijednosti.

Čl. 8. st. 4. Zakona o financiranju jedinica lokalne i područne (regionalne) samouprave propisuje da referentna vrijednost kapaciteta ostvarenih poreznih prihoda iz st. 1. ovoga članka za gradove jest petogodišnji prosjek ukupnih prihoda od poreza na dohodak ostvarenih na području svih gradova te prihoda od prireza koje bi gradovi ostvarili uvođenjem najviše propisane stope prireza, po glavi stanovnika svih gradova.

Čl. 8. st. 5. Zakona o financiranju jedinica lokalne i područne (regionalne) samouprave propisuje da kapacitet ostvarenih poreznih prihoda iz st. 1. ovoga članka županije jest petogodišnji prosjek ukupnih prihoda od poreza na dohodak ostvarenih na području županije pomnožen s udjelom koji županijama pripada temeljem raspodjele prihoda od poreza na dohodak propisane čl. 5. st. 2. toč. 2. ovoga Zakona, po glavi stanovnika pojedine županije.

Čl. 8. st. 6. Zakona o financiranju jedinica lokalne i područne (regionalne) samouprave propisuje da referentna vrijednost kapaciteta ostvarenih poreznih prihoda iz st. 1. ovoga članka za županije jest petogodišnji prosjek ukupnih prihoda od poreza na dohodak ostvarenih na području svih županija 
Dr. sc. Zoran Šinković: Financiranje jedinica lokalne i područne (regionalne)...

Zbornik radova Pravnog fakulteta u Splitu, god. 56, 1/2019., str. 223.- 250.

u 2018. godini iznosi za općine 1927,00 kuna, gradove 2585,00 kuna i županije 319,00 kuna. Referentna vrijednost u 2019. godini iznosi za općine 1942,77 kuna, gradove 2545,42 kuna i županije 315,60 kuna. $^{63}$

Sredstva fiskalnog izravnanja za gradove u 2019. godini procjenjuju se na 976 milijuna kuna, odnosno 68 milijuna kuna više nego 2018. godine. ${ }^{64}$

Ovakvim načinom dodjele pomoći postiže se pojednostavljenje postojećeg sustava dodjele pomoći jedinicama lokalne i područne (regionalne) samouprave iz

pomnožen s udjelom koji županijama pripada temeljem raspodjele prihoda od poreza na dohodak propisane čl. 5. st. 2. toč. 2. ovoga Zakona, po glavi stanovnika svih županija.

Čl. 8. st. 7. Zakona o financiranju jedinica lokalne i područne (regionalne) samouprave propisuje od izračuna referentnih vrijednosti kapaciteta ostvarenih poreznih prihoda iz st. 4. i 6. ovoga članka isključuje se Grad Zagreb.

Čl. 9. st. 1. Zakona o financiranju jedinica lokalne i područne (regionalne) samouprave propisuje da sredstva fiskalnog izravnanja u punom iznosu za pojedinu općinu predstavljaju razliku referentne vrijednosti kapaciteta ostvarenih poreznih prihoda za općine iz čl. 8. st. 3. ovoga Zakona i kapaciteta ostvarenih poreznih prihoda općine iz čl. 8. st. 2. ovoga Zakona pomnoženu s ukupnim brojem stanovnika pojedine općine.

Čl. 9. st. 2. Zakona o financiranju jedinica lokalne i područne (regionalne) samouprave propisuje da sredstva fiskalnog izravnanja u punom iznosu za pojedini grad predstavljaju razliku referentne vrijednosti kapaciteta ostvarenih poreznih prihoda za gradove iz čl. 8. st. 4. ovoga Zakona i kapaciteta ostvarenih poreznih prihoda grada iz čl. 8. st. 2. ovoga Zakona pomnoženu s ukupnim brojem stanovnika pojedinog grada.

Čl. 9. st. 3. Zakona o financiranju jedinica lokalne i područne (regionalne) samouprave propisuje da sredstva fiskalnog izravnanja u punom iznosu za pojedinu županiju predstavljaju razliku referentne vrijednosti kapaciteta ostvarenih poreznih prihoda za županije iz čl. 8. st. 6. ovoga Zakona i kapaciteta ostvarenih poreznih prihoda županije iz čl. 8. st. 5. ovoga Zakona pomnoženu s ukupnim brojem stanovnika pojedine županije.

Čl. 9. st. 4. Zakona o financiranju jedinica lokalne i područne (regionalne) samouprave propisuje da zbroj sredstava fiskalnog izravnanja u punom iznosu iz st. 1. 2. i 3. ovoga članka predstavlja ukupna sredstva fiskalnog izravnanja u punom iznosu.

Čl. 9. st. 5. Zakona o financiranju jedinica lokalne i područne (regionalne) samouprave propisuje da jedinicama lokalne i područne (regionalne) samouprave koje imaju pravo na sredstva fiskalnog izravnanja temeljem čl. 8. st. 1. ovoga Zakona na dnevnoj bazi raspodjeljivat će se sredstva prikupljena iz udjela za fiskalno izravnanje iz čl. 5. st. 2. toč. 4. ovoga Zakona, a temeljem udjela sredstava fiskalnog izravnanja u punom iznosu za pojedinu općinu, grad i županiju iz st. 1. 2. i 3. ovoga članka u ukupnim sredstvima fiskalnog izravnanja u punom iznosu iz st. 4. ovoga članka.

Čl. 9. st. 6. Zakona o financiranju jedinica lokalne i područne (regionalne) samouprave propisuje da udio sredstava fiskalnog izravnanja u punom iznosu za pojedinu općinu, grad i županiju iz st. 1. 2. i 3. ovoga članka u ukupnim sredstvima fiskalnog izravnanja u punom iznosu iz st. 4. ovoga članka utvrđuje odlukom ministar financija za svaku proračunsku godinu.

63 Za potrebe izračuna fiskalnog izravnanja u 2018. godini koriste se podaci za razdoblje od 2012. do 2016. godine. Za potrebe fiskalnog izravnanja u 2019. godini koriste se podaci za razdoblje od 2013. do 2017. godine. Podrobnije vidjeti u: Odluka o udjelu sredstava fiskalnog izravnanja za pojedinu općinu, grad i županiju u ukupnim sredstvima fiskalnog izravnanja u 2019. godini - Ministarstvo financija Ministar financija, Klasa: 015-01/18-01/33., Urbroj: 513-05-06-18-1., Zagreb, 27. rujna 2018. godine.

64 Napominjemo da se radi o procjeni temeljem očekivane naplate poreza na dohodak u 2019. godini zbog čega su moguća odstupanja u slučaju značajnijih promjena u naplati. Na visinu ukupno procijenjenih sredstava negativno će utjecati izmjena praga za oporezivanje dohotka po stopi od $36 \%$ (procijenjeni utjecaj jest $1 \%$ ), a potencijalno pozitivan učinak može se očekivati od paušalnog poreza na iznajmljivanje soba, postelja i organiziranje kampova. S obzirom na to da u ovom trenutku nije poznato kakve će stope paušalnog poreza odrediti lokalne jedinice, nije moguće procijeniti utjecaj na fond izravnanja. Navedeno prema: http://www.udruga-gradova.hr/procjena-fiskalnog-izravnanja-za-2019-godinu/. 
državnog proračuna s jasno utvrđenim kriterijima koji su transparentni i predvidljivi. Učinkovitiji model fiskalnog izravnanja koji će s ciljem osigurati svim lokalnim jedinicama potencijal za pružanje usporedive razine javnih usluga uz usporedivu razinu poreznog opterećenja.

\subsubsection{Zaduživanje}

U literaturi se mogu naći raznovrsne definicije javnog zajma, jer sam „pojam javnog zajma nije jednoznačan. On se jednom rabi da bi se njime označio ugovor koji se sklapa između države-dužnika i njenih vjerovnika, a drugi put se pod terminom javni zajam podrazumijeva predmet tog ugovora" ". ${ }^{65}$

Županija, grad i općina može se zaduživati uzimanjem kredita, zajmova i izdavanjem vrijednosnih papira prema čl. 86. Zakona o proračunu.

Ponajprije jedno od uvriježenih načela javnih financija, prema kojem se kapitalni rashodi financiraju kapitalnim prihodima, nalaže svojevrsno razlikovanje prihodnih izvora dugoročnih gradskih investicijskih smjerova. K tomu, u suvremenim uvjetima, proračuni gradova, pored svojih klasičnih funkcija, sve više preuzimaju i funkciju investicijskog fonda. Tu, sve prisutniju funkciju proračuna gradske vlasti ne mogu uspješno ostvariti koristeći se fiskalnim izvorima s obzirom na to da su kapitalni troškovi izgradnje lokalne infrastrukture iznimno veliki i, po pravilu, premašuju fiskalni kapacitet lokalnih i gradskih jedinica. Najčešće se pritom spominje zaduživanje (kreditima i municipalnim obveznicama), javno-privatno partnerstvo, financiranje porasta prihoda, razvojne naknade. ${ }^{66}$

\section{OSTVARENJE PRORAČUNA ŽUPANIJA, GRADOVA I OPĆINA U 2017. GODINI}

Nakon izložene normativne analize financiranja jedinica lokalne i područne (regionalne) samouprave - županija, gradova i općina u Republici Hrvatskoj, sada će biti više riječi o ostvarivanju njihovih proračuna.

U razdoblju 2014. - 2017. godine nije bilo većih oscilacija u prosječnim ukupnim i prosječnim prihodima po stanovniku lokalnih jedinica, tek je kod županija uočen porast prosječnih ukupnih prihoda, a kod općina porast prosječnih prihoda po stanovniku.

U 2017. godini najviši su prosječni ukupni prihodi županija (202 milijuna kuna), slijede ih gradovi sa Zagrebom (123 milijuna kuna) i gradovi bez Zagreba (72 milijuna kuna), a na začelju su općine ( 9 milijuna kuna). Po prosječnom prihodu po stanovniku, situacija se razlikuje, pa tako vode gradovi (sa Zagrebom 4314,00

65 Ba. Jelčić, Javne financije, Informator, Zagreb, 1997., str. 434.

66 T. Rogić Lugarić, „Financijski aspekti položaja velikih gradova“, Hrvatska javna uprava, god. 10., br. 3/2010., Pravni fakultet Sveučilišta u Zagrebu, Zagreb, 2010., str. 687. 
kuna, bez Zagreba 4284,00 kuna), slijede ih općine (3863,00 kuna), a na začelju su županije (1319,00 kuna). ${ }^{67}$

Dvanaest je gradova i čak 33 općine ostvarilo prihode po stanovniku veće od Zagreba (8177,00 kuna).

Čak dvije trećine općina, te više od $60 \%$ gradova, imaju prihode po stanovniku manje od prosjeka općina, odnosno gradova.

U razdoblju 2014. - 2017. godine nije bilo većih oscilacija u odnosima prosjeka lokalnih jedinica, tek županije u 2017. godini bilježe zamjetan porast prosječnih ukupnih prihoda u odnosu na prethodne godine (oko $10 \%$ ), a općine znatan porast prosječnih prihoda po stanovniku u 2017. godini u odnosu na 2014. godinu (više od $20 \%$ ).

$\mathrm{U}$ istom su razdoblju općine u prosjeku imale vrlo uravnotežene proračune, gradovi bez Zagreba uglavnom su bili u blagom suficitu, dok su kod gradova sa Zagrebom i županija bile prilične oscilacije..$^{68}$

U Republici Hrvatskoj postoje velike razlike između najbogatijih i najsiromašnijih lokalnih jedinica.

Po prihodima po stanovniku s 26.109,00 kuna izrazito odskače općina Civljane, a slijede je općine Baška (14.985,00 kuna) i Karlobag (14.785,00 kuna). Najmanje prihode po stanovniku imaju općine Pojezerje (1035,00 kuna), Maruševec (1201,00 kuna) i Sveti Juraj na Bregu (1303,00 kuna). Kao i u 2016. godini, po ukupnim prihodima vodeća je općina Medulin (80,3 milijuna kuna), a na začelju je Pojezerje (0,9 milijuna kuna). Iznos ukupnih prihoda samoga Medulina jednak je zbroju ukupnih prihoda tridesetak općina s najnižim ukupnim prihodima. ${ }^{69}$

Prema prihodima po stanovniku, među gradovima vode Nin s 13.601,00 kunom i Novalja s 10.623,00 kune, a na začelju su Lepoglava s 1548,00 kuna, Novi Marof s 1647,00 kuna i Donji Miholjac s 1711,00 kuna.

Izuzme li se grad Zagreb koji sa 6,57 milijardi kuna ostvaruje gotovo $42 \%$ ukupnih prihoda svih gradova, po ukupnim su prihodima najjači Split sa 792 milijuna kuna i Rijeka sa 671 milijunom kuna. Na začelju su Komiža i Klanjec, oba sa 6,1 milijuna kuna. Sam Split ostvaruje ukupnih prihoda otprilike koliko 45 gradova s najnižim ukupnim prihodima zajedno.

Također je presudan utjecaj položaja uz more na financijsko stanje gradova i općina. Od 19 općina s prihodom po stanovniku većim od 10.000,00 kuna samo Civljane, Lokvičići, Dugopolje i Saborsko nisu na moru. Među više od dvije stotine općina s prihodom manjim od 2800,00 kuna po stanovniku samo su dvije - Vela Luka i Sukošan - na moru, a tek njih oko 7 \% nalazi se u jadranskoj Hrvatskoj. Među sedamdesetak općina s prihodom po stanovniku manjim od 2000,00 kuna, ni jedna nije na moru, a samo se jedna - Pojezerje - nalazi u jadranskoj Hrvatskoj.

67 K. Ott i drugi, „Ostvarenje proračuna općina, gradova i županija u 2017.“, Newsletter-povremeno glasilo Instituta za javne financije, Institut za javne financije, Zagreb, 2018., str. 2.

68 Ibid., str. 3.

69 Ibid., str. 4. 
I gradovi s najviše prihoda po stanovniku - Nin i Novalja - nalaze se uz more, za razliku od gradova s najmanje prihoda po stanovniku (Lepoglava, Novi Marof i Donji Miholjac). Također, među prvih 25 gradova s prihodom višim od 6000,00 kuna po stanovniku na moru nisu samo Zagreb, Obrovac, Vukovar i Pazin, dok su među šezdesetak gradova s prihodom po stanovniku nižim od 3500,00 kuna samo dva (Kaštela s 2581,00 kunom i Ploče s 3468,00 kuna) na moru.

Trinaest općina s najvećim ukupnim prihodima - sve iznad 30 milijuna kuna nalaze se u jadranskoj Hrvatskoj. ${ }^{70}$

Česte su velike neusklađenosti između prihoda i rashoda pojedinih lokalnih jedinica unutar jedne godine.

Veliki je broj općina u kojima su ukupni rashodi znatno viši od prihoda, primjerice u Goričanu preko $150 \%$, Konjščini i Bosiljevu preko $120 \%$, Gornjem Knegincu preko $90 \%$, Strahonincu i Pojezerju oko 70 \%, Jalžabetu $55 \%$, Viru, Tkonu i Sračincu oko $50 \%$ itd. Kod gradova nema tako velikih odstupanja, no ističu se Orahovica sa $70 \%$, Labin s $35 \%$ i Trilj s $30 \%$ većim rashodima od prihoda.

Brojne su i općine u kojima su ukupni prihodi znatno viši od rashoda, primjerice u Lekeniku $90 \%$, Privlaci (Zadar) $75 \%$, Vižinadi i Sikirevcima $70 \%$ itd. Kod gradova se ističu Opuzen s $90 \%$, Nin $76 \%$, Slunj $44 \%$ itd. $^{71}$

Promotrimo li pak zakonski okvir formalnog elementa porezne autonomije u Republici Hrvatskoj, jasno je da možemo govoriti o „izvedenoj“ moći oporezivanja, pri čemu je vidljiva dominacija tzv. isključivih poreza. No, dok je na razini lokalnih jedinica (gradova i općina) isključivost ublažena dvjema mogućnostima: izborom uvođenja lokalnih poreza (ali samo onih zakonom utvrđenih) i propisivanjem visine stopa lokalnih poreza (unutar zakonom utvrđenih granica), na razini županija tih mogućnosti nema: županije ne mogu birati poreze koje će uvesti niti mogu utjecati na visinu stopa (vidjeti čl. 3.-19., čl. 20.-29. i čl. 45.-49. Zakona o lokalnim porezima.). ${ }^{72}$

Radi sprečavanja nejednakog kruga javnih usluga stanovništvu koje živi u različitim lokalnim jedinicama, s različitim interesno-političkim usmjerenjima njihovih lokalnih vlasti i s različitim mogućnostima, središnja vlast može naložiti da sve lokalne jedinice obave određeni krug poslova, odnosno pružaju određeni krug javnih usluga za svoje stanovništvo uz jednake ili slične uvjete i podjednaku kvalitetu tih usluga. Taj se dio lokalnog samoupravnog djelokruga zove naloženi, obligatorni ili minimalni samoupravni djelokrug. ${ }^{73}$

70 Ibid.

71 Ibid.

72 T. Rogić Lugarić, „Financiranje jedinica lokalne i područne (regionalne) samouprave“ u: J. Kregar i drugi, Decentralizacija, Centar za demokraciju i pravo Miko Tripalo, Sveučilišta tiskara Zagreb, Zagreb, 2011., str. 66.

73 I. Koprić, „Kroz integraciju u decentralizaciju: integrirano lokalno javno upravljanje u Hrvatskoj“, Forum za javnu upravu, Izazovi upravljanja: decentralizacija i dekoncentracija obavljanja javnih poslova, Friedrich-Ebert-Stiftung, Institut za javnu upravu, Zagreb, 2018., str. 11. 
Na temelju izvršene normativne analize i financijskih pokazatelja vezanih za poslovanje županija, gradova i općina, može se predložiti sljedeće:

1) Ministarstvo financija na svojim mrežnim stranicama nudi proračune $i$ bilance svih lokalnih jedinica, no za potpunije informiranje o ukupnom i stvarnom financijskom stanju lokalnih jedinica neophodno je da Vlada Republike Hrvatske odredi nadležna ministarstva koja će za sve pravne osobe u vlasništvu i suvlasništvu lokalnih jedinica (bez obzira na postotak suvlasništva), kao i za ustanove koje su lokalne jedinice osnovale, objaviti jedinstvene, ažurne, strojno čitljive, online baze osnovnih podataka (popis s adresama i kontaktima) kao i njihovih bilanci te računa dobiti i gubitka. ${ }^{74}$

2) Ministarstvo financija - uz objavljene proračune i bilance svih lokalnih jedinica mora početi objavljivati pojašnjenja metodologije, obuhvata podataka i promjena u serijama podataka. ${ }^{75}$

3) Lokalne jedinice bi, također, morale na mrežnim stranicama u strojno čitljivom formatu objavljivati potpuna godišnja i polugodišnja izvješća o izvršenju proračuna (uključujući obrazloženja ostvarenja prihoda i primitaka te rashoda i izdataka) koja građanima olakšavaju razumijevanje proračuna. Bez narativnih objašnjenja, same brojke nisu dovoljne za razumijevanje proračuna. ${ }^{76}$

4) Treba istovremeno provoditi upravnu i fiskalnu decentralizaciju na svim razinama vlasti, državna, regionalna i lokalna, odnosno nije svrsishodno paušalno provođenje pojedinih aspekata decentralizacije (na primjer samo upravna ili fiskalna). Pozitivno je za istaknuti da u tom smjeru ide i Vlada Republike Hrvatske. ${ }^{77}$

5) Jasna podjela ovlaštenja i poslova između državne, regionalne i lokalne razine vlasti koja bi trebala uključivati u nekim segmentima i novu sistematizaciju radnih mjesta $^{78}$ posebice u poreznoj upravi, odnosno racionalizacija sustava agencija, zavoda i slično.

6) Bolja suradnja između državne, regionalne i lokalne vlasti uz poštovanje načela dobre vjere.

74 K. Ott i drugi, Ostvarenje... o. c., str. 5.

75 Ibid.

76 Ibid., str. 5-6.

77 Ciljevi Strateškog plana Ministarstva uprave za razdoblje 2019. - 2021. godine su sljedeći: 1) unaprijediti sustav javne uprave, 2) izgraditi kvalitetnu i korisnički usmjerenu upravu, 3) unapređivanje službeničkog sustava, 4) digitalizacija javnih usluga i internih procesa u javnoj upravi.

78 Općenito, decentralizacijski proces najviše je utjecao na personalne kapacitete u kvantitativnom smislu, osobito u županijama. Detaljnija analiza porasta broja službenika upozorava međutim da to ipak nije jedini razlog značajnog rasta zaposlenosti. S druge strane, decentralizacija nije imala značajan utjecaj na porast profesionalnosti službenika i razvoj modernog sustava upravljanja ljudskim potencijalima u jedinicama lokalne i područne (regionalne) samouprave. Utjecaj procesa decentralizacije na kvantitativne, ali ne i na kvalitativne pokazatelje personalnih kapaciteta može se objasniti okolnošću da proces decentralizacije u Republici Hrvatskoj nije bio istinski. Takva „oklijevajuća“ decentralizacija, karakteristična za mnoge postsocijalističke zemlje, prouzročena je nizom institucionalnih, financijskih, kulturoloških i političkih faktora, a njihova dugogodišnja rezistencija i dalje je problem koji zahtijeva višeslojan i dugoročan pristup. Navedeno prema: G. Marčetić i drugi, „Utjecaj procesa decentralizacije na jačanje personalnih kapaciteta hrvatske lokalne i područne (regionalne) samouprave“, Hrvatska $i$ komparativna javna uprava, god. 17., br. 3., Institut za javnu upravu, Zagreb, 2017., str. 430. 
7) Poštovanje načela zakonitosti, odgovornosti i transparentnosti odnosno jačanja sustava javne odgovornosti i javnog nadzora ne samo lokalnih dužnosnika, nego i državnih.

8) Treba težiti smanjenju broja odnosno spajanju jedinica lokalne samouprave (gradova i općina) s posebnim naglaskom na zbrinjavanje zaposlenika, čiji kapacitet ostvarenih prihoda nije dostatan za financiranje javnih rashoda. Pri tome treba uvažavati ustavnu podjelu nadležnosti i zadaća u nekoj državi, politički i gospodarski nacrt ovih odnosa, povijesnu tradiciju, odnosno broj stanovnika, financijske potrebe, financijsku snagu, dohodak po stanovniku i porezno opterećenje pojedine jedinice lokalne samouprave. Također je neophodno utvrditi koje poslove jedinice lokalne samouprave obavljaju i s kojim upravnim (administrativnim) i financijskim kapacitetima raspolažu za izvršenje tih poslova te koje nove poslove mogu preuzeti.

\section{ZAKLJUČAK}

Jedinice lokalne i područne (regionalne) samouprave imaju važnu ulogu u upravljanju, organizaciji i izravnom pružanju javnih usluga građanima. U nastojanju izgradnje djelotvorne, učinkovite i ekonomične javne uprave potrebno je uspostaviti i djelotvoran sustav lokalne i područne (regionalne) samouprave. Reforma lokalne i područne (regionalne) samouprave dio je sveobuhvatne reforme javne uprave.

Krajni cilj jest poboljšati funkcionalnu raspodjelu nadležnosti i učinkovitost jedinica lokalne i područne (regionalne) samouprave, vodeći pri tome računa o ravnomjernom pružanju usluga građanima. Jedinice lokalne i područne (regionalne) samouprave trebaju imati upravne (administrativne) i financijske kapacitete za kvalitetno, učinkovito i samostalno planiranje, financiranje i pružanje usluga iz svojeg zakonom propisanog djelokruga kao i za preuzimanje novih poslova te obavljanje decentraliziranih poslova iz nadležnosti središnje državne uprave, a njihova tijela trebaju međusobno surađivati i obavljati poslove iz svoga djelokruga u interesu samih jedinica. ${ }^{79}$

Lokalna samouprava ne znači samo imati pravo na nju, već i odgovornost prema njoj u smislu potpunog i ravnomjernog zadovoljavanja javnih potreba. ${ }^{80}$

Republika Hrvatska primjenjuje mješoviti sustav financiranja jedinica lokalne i područne (regionalne) samouprave kao i druge suvremene države. Mješoviti sustav uklanja gospodarske i socijalne neuravnoteženosti između različitih razina vlasti ustanovljavanjem odgovarajućeg sustava fiskalnog izravnanja, odnosno održava neophodni stupanj jedinstvenosti i jednakosti kod propisivanja poreza i drugih davanja, s ciljem uklanjanja ,fiskalnog kaosa“. U skladu s time, jedinice lokalne i područne (regionalne) samouprave stječu prihode iz: 1) vlastitih izvora, 2) zajedničkog poreza, 3) zajedničkih prihoda od naknada za koncesije, 4) pomoći, 5) zaduživanja.

79 Ciljevi... o. c., str. 7.

80 B. Mauhar, Lokalna ... o. c., str. 207. 
Treba istovremeno provoditi upravnu i fiskalnu decentralizaciju na svim razinama vlasti, državna, regionalna i lokalna, odnosno jačanje sustava javne odgovornosti i javnog nadzora - razvijanje mehanizama odgovornosti lokalnih dužnosnika, u kojem bi kontekstu instrumenti lokalne demokracije i neposrednog sudjelovanja građana bili posebno poticajni. ${ }^{81} 82$

Koliko ovlasti imaju jedinice lokalne i područne (regionalne) samouprave ovisi o: 1) rasponu javnih usluga koje financiraju, 2) dostatnosti prihoda za financiranje, 3) razmjerima ovlasti što ih lokalne vlasti imaju u alociranju proračunskih sredstava, 4) razmjerima ovlasti u određivanju poreznih stopa lokalnih poreza i korisničkih naknada. Stoga bi u skladu s navedenim ovlastima (a uvažavajući kriterije broja stanovnika, financijske potrebe, financijsku snagu, dohodak po stanovniku i porezno opterećenje pojedine jedinice lokalne samouprave) trebalo smanjiti dosadašnji broj odnosno spajati jedinice lokalne samouprave (gradove i općine) čiji kapacitet ostvarenih prihoda nije dostatan za financiranje javnih rashoda s posebnim naglaskom na zbrinjavanje zaposlenika. ${ }^{83}$

\section{Popis literature}

H. Arbutina, IV. poglavlje „Financijsko izravnanje“, u: Bo. Jelčić i drugi, Financijsko pravo i financijska znanost, Narodne novine, Zagreb, 2008.

V. J. Bibow i drugi, Fiskalische Austeritätspolitik und Lohnsenkung: Eine fatale, aber unverstandene Kombination als „Anpassungs - Programm“ in den Eurokrisenländern, Arbeitskammer des Saarlandes, 2017.

S. M. Bouvier, Introduction au droit fiscal général et à la théorie de limpôt, LGDJ lextenso editions, Paris, 2010.

Bundesministerium der Finanzen, 2017.

Burki i drugi, Beyond the Center: Decentralizing the State, The World Bank Washington D. C., 1999.

${ }_{81}$ T. Rogić Lugarić, „Financiranje jedinica lokalne i područne (regionalne) samouprave“ u: J. Kregar i drugi, Decentralizacija... o. c., str. 82 .

${ }_{82}$ U Europskoj uniji vanjska financijska revizija jedinica lokalne i regionalne samouprave provodi se primjenom četiriju različitih metoda, no samo šest država članica (Njemačka, Francuska, Španjolska, Austrija, Poljska i Nizozemska) koriste regionalne revizijske institucije (RAI). One se još mogu nazivati i regionalnim računovodstvenim sudovima ili komorama. Neovisnost RAI-a zajamčena je ustavom ili zakonom država koje ih koriste, a neovisnosti u prilog ide i znatan stupanj njihove financijske autonomije. Statuti RAI-a propisuju zabranu bilo kakvog političkog ili profesionalnog utjecaja na članove RAI-a. U nekim državama, kao što su Nizozemska ili Poljska, nisu postojala vanjska revizijska tijela koja bi se bavila lokalnim samoupravnim jedinicama (i brojnim agencijama koje one osnivaju). S druge strane, ustrojstvo nekih država, federalno (u Njemačkoj i Austriji) ili kvazifederalno (u Španjolskoj), rezultiralo je uspostavom decentraliziranih revizijskih tijela. Podrobnije vidjeti u: R. Chouvel, „External Financial Auditing of Local and Regional Governments by Regional Audit Institutions in the European Union“, Hrvatska i komparativna javna uprava, god. 17., br. 1/2007., Institut za javnu upravu, Zagreb, 2017., str. 57-80

83 Čak dvije trećine općina te više od $60 \%$ gradova imaju prihode po stanovniku manje od prosjeka općina, odnosno gradova. 
R. Chouvel, „External Financial Auditing of Local and Regional Governments by Regional Audit Institutions in the European Union“, Hrvatska $i$ komparativna javna uprava, god. 17., br. 1/2007., Institut za javnu upravu, Zagreb, 2017.

C. Conroy, „Fiscal and Federal Structures in Germany“ u: T. T. Minassian i drugi, Fiscal Federalism and Governance in the European Union, Project on 21st Century City Governance, Global Economy and Development at Brookings, 2017.

V. Đulabić, Lokalna samouprava i decentralizacija u Hrvatskoj, Rezultati istraživanja $i$ preporuke za poboljšanje politike decentralizacije, Friedrich-Ebert-Stiftung, Zagreb, 2018.

R. Ebel i drugi, Fiscal Decentralization: Is It Happening? How Do We Know?, Andrew Young School of Policy Studies, Georgia State University, Atlanta, GA, USA, 2001.

ECPRD Request no. 3159., Duties and financing of municipalities, 12. July 2016.

J. Gorčić, Fiskalni federalizam, lokalna samouprava i budžetske politike, Evropski centar za mir i razvoj Univerziteta za mir Ujedinjenih nacija, Institut za poslovne finansije, Beograd, 2013.

A. H. Hallett, „Fiscal autonomy vs. Fiscal federalism in the euro zone“, Economia Politica, Volume 34., Issue 2/2017., Journal of Analytical and Institutional Economics, Springer International Publishing Switzerland, 2017.

T. Hart i drugi, „Fiscal decentralisation“, A public financial management introductory guide, Overseas Development Institute, London, 2016.

Ba. Jelčić, Javne financije, Informator, Zagreb, 1997.

Bo. Jelčić, V. poglavlje ,'Javni rashodi’ Državni proračun (budžet)“ u: Bo. Jelčić i drugi, Financijsko pravo i financijska znanost, Narodne novine, Zagreb, 2002.

M. Klarić, „Problems and developments in the Croatian local self-government“, Zbornik radova Pravnog fakulteta u Splitu, god. 54., br. 4/2017., Pravni fakultet Sveučilišta u Splitu, Split, 2017.

I. Koprić, „Decentralizacija i dobro upravljanje gradovima“, Hrvatska javna uprava, god. 9., br. 1/2009., Pravni fakultet Sveučilišta u Zagrebu, Zagreb, 2009.

I. Koprić, „Kroz integraciju u decentralizaciju: integrirano lokalno javno upravljanje u Hrvatskoj", Forum za javnu upravu, Izazovi upravljanja: decentralizacija i dekoncentracija obavljanja javnih poslova, Friedrich-Ebert-Stiftung, Institut za javnu upravu, Zagreb, 2018.

J. Litvack i drugi, Rethinking Decentralization in Developing Countries, The World Bank Washington D. C., 1998.

R. Manojlović, „Javna uprava i politički sustav Savezne Republike Njemačke: modernizacija kroz očuvanje tradicije“, Hrvatska i komparativna javna uprava, god. 15., br. 1/2015., Institut za javnu upravu, Zagreb, 2015.

G. Marčetić i drugi, „Lokalna samouprava u Njemačkoj i Francuskoj“, Hrvatska javna uprava, god. 10., br. 1/2010., Pravni fakultet Sveučilišta u Zagrebu, Zagreb, 2010.

G. Marčetić i drugi, „Utjecaj procesa decentralizacije na jačanje personalnih kapaciteta hrvatske lokalne i područne (regionalne) samouprave“, Hrvatska i komparativna javna uprava, god. 17., br. 3., Institut za javnu upravu, Zagreb, 2017. 
B. Mauhar, „Lokalna samouprava u Republici Hrvatskoj između htijenja i mogućnosti“ $\mathrm{u}$ : Zbornik radova s međunarodnog znanstvenog skupa „Uloga države u socio-ekonomskom razvoju nacionalnog gospodarstva" u povodu 80. godišnjice života prof. emeritusa Božidara Jelčića, Visoka poslovna škola Libertas u Zagrebu, Zagreb, 2010.

K. Ott i drugi, „Ostvarenje proračuna općina, gradova i županija u 2017.“, Newsletter - povremeno glasilo Instituta za javne financije, Institut za javne financije, Zagreb, 2018.

E. Pusić, Država i državna uprava, Pravni fakultet u Zagrebu, Zagreb, 1999.

Z. Petak, „Politika decentralizacije kao svjetski trend“, Lokalna samouprava pred reformskim izazovima, Vodič kroz lokalnu demokraciju, Stina, Split, 2005.

Strateški plan Ministarstva uprave za razdoblje 2019. - 2021. godine, Ministarstvo uprave, Zagreb, 2018.

T. Rogić Lugarić, „Financijski aspekti položaja velikih gradova“, Hrvatska javna uprava, god. 10., br. 3/2010., Pravni fakultet Sveučilišta u Zagrebu, Zagreb, 2010.

T. Rogić Lugarić, „Financiranje jedinica lokalne i područne (regionalne) samouprave“ u: J. Kregar i drugi, Decentralizacija, Centar za demokraciju i pravo Miko Tripalo, Sveučilišta tiskara Zagreb, Zagreb, 2011.

T. Rogić Lugarić, „Normativna decentralizacija u Hrvatskoj i njezine granice“, Društvena istraživanja, god. 14., br. 6/2005., Institut društvenih znanosti Ivo Pilar, Zagreb, 2005.

D. Rondinelli, «What is Decentralization?» in: J. Litvack and J. Seddon (editors), Decentralization Briefing Notes, The World Bank Institute, Washington D. C., 2000.

T. Šimić i drugi, Fiskalna decentralizacija i pitanje teritorijalnog izravnanja u Republici Hrvatskoj, Pravo i porezi, br. 3/2008.

H. Šimović, Fiskalni federalizam u Europskoj uniji: odnosi fiskalne nadležnosti, Zbornik radova Pravnog fakulteta u Zagrebu, god. 55., br. 2/2005., Pravni fakultet Sveučilišta u Zagrebu, Zagreb, 2005.

D. Špoljarić i drugi, Normativna osnova financiranja lokalnih razina u Republici Hrvatskoj, FIP - Financije i pravo, god. 5., br. 1/2017., Visoko učilište Effectus - Visoka škola za financije i pravo, Zagreb, 2017.

\section{Pravni propisi \\ Republika Hrvatska}

Državni proračun Republike Hrvatske za 2018. godinu i projekcije za 2019. i 2020. godinu, Narodne novine, br. 124/17.

Europska povelja o lokalnoj samoupravi, Narodne novine - Međunarodni ugovori, br. 14/97, 2/07, 4/08 i 5/08.

Odluka o razvrstavanju jedinica lokalne i područne (regionalne) samouprave prema stupnju razvijenosti, Narodne novine, br. Narodne novine, br. 132/17. 
Odluka o udjelu sredstava fiskalnog izravnanja za pojedinu općinu, grad i županiju u ukupnim sredstvima fiskalnog izravnanja u 2019. godini - Ministarstvo financija - Ministar financija, Klasa: 015-01/18-01/33., Urbroj: 513-05-06-18-1., Zagreb, 27. rujna 2018. godine.

Pravilnik o načinu ostvarivanja porezne olakšice za obavljanje djelatnosti na području grada Vukovara i na potpomognutim područjima, Narodne novine, br. 18/08.

Pravilnik o proračunskim klasifikacijama, Narodne novine, br. 26/10 i 120/13.

Pravilnik o proračunskom računovodstvu i računskom planu, Narodne novine, br. 124/12, 115/15, 87/16 i 3/18.

Pravilnik o uvjetima, opsegu i naknadi za obavljanje poslova utvrđivanja, evidentiranja, nadzora, naplate i ovrhe radi naplate poreza jedinica lokalne i područne (regionalne) samouprave, Narodne novine br. 1/17.

Uredba o indeksu razvijenosti, Narodne novine, br. 131/17.

Uredba o načinu financiranja decentraliziranih funkcija te izračuna iznosa pomoći izravnanja za decentralizirane funkcije jedinica lokalne i područne (regionalne) samouprave za 2018. godinu, Narodne novine, br. 7/2018.

Ustav Republike Hrvatske, Narodne novine, br. 56/90, 135/97, 08/98, 113/00, 124/00, 28/01, 41/01, 55/01, 76/10, 85/10 i 05/14.

Zakon o financiranju jedinica lokalne i područne (regionalne) samouprave, Narodne novine, br. 127/17.

Zakon o izvršavanju državnog proračuna Republike Hrvatske za 2018. godinu, Narodne novine, br. 124/17.

Zakon o koncesijama, Narodne novine, br. 69/17.

Zakon o komunalnom gospodarstvu, Narodne novine, br. 68/18.

Zakon o lokalnim porezima, Narodne novine, br. 115/16 i 101/17.

Zakon o lokalnoj i područnoj (regionalnoj) samoupravi, Narodne novine, br. 33/01, 60/01, 129/05, 109/07, 125/08, 36/09, 150/11, 144/12, 19/13, 137/15 i 123/17.

Zakon o područjima posebne državne skrbi, Narodne novine, br. 86/08, 57/11, 51/13, 148/13, 76/14, 147/14 i 18/15.

Zakon o područjima županija, gradova i općina u Republici Hrvatskoj, Narodne novine, br. 86/06, 125/06 - ispravak, 16/07 - ispravak, 46/10 - ispravak, 145/10, 37/13, 44/13, 45/13, 110/15, Odluka USRH - 95/08.

Zakon o porezu na dohodak, Narodne novine, br. 115/16.

Zakon o porezu na promet nekretnina, Narodne novine, br. 115/16.

Zakon o proračunu, Narodne novine, br. 87/08, 136/12 i 15/15.

Zakon o regionalnom razvoju Republike Hrvatske, Narodne novine, br. 147/14 i 123/17. 


\section{Kraljevina Španjolska}

Real Decreto Legislativo 2/2004., de 5 de marzo, por el que se aprueba el texto refundido de la Ley Reguladora de las Haciendas Locales.

\section{Savezna Republika Njemačka}

Grundgesetz für die Bundesrepublik Deutschland vom 23. Mai 1949., (BGB1. S. 1), zuletzt geändert durch Artikel 1. des Gesetzes vom 13. Juli 2017. (BGB1. I S. 2347).

\section{MREŽNI IZVORI}

https://uprava.gov.hr/o-ministarstvu/ustrojstvo/uprava-za-politicki-sustav-iorganizaciju-uprave/lokalna-i-podrucna-regionalna-samouprava/popis-zupanija-gradovai-opcina/846

http://www.mfin.hr/hr/lokalna-samouprava

www.finanzen-und-steuern.de

http://www.udruga-gradova.hr/procjena-fiskalnog-izravnanja-za-2019-godinu/

\section{FINANCING OF LOCAL AND REGIONAL SELF-GOVERNMENT}

The territorial organization of modern states rests on the principles of decentralization, which includes the political, administrative and financial independence of the lower levels of government. It is a fundamental principle that no function, no job or task can be assigned to a certain level of government or body of government without the funds being provided. Local and regional selfgovernment are one of the most important areas of strategic importance for the development of democratic and quality public policies in the Republic of Croatia. The relationship between local and regional self-government and users can also be seen as a parallel process of strengthening the responsibility of local units for overall quality and «offering» public services in the local area. Therefore local and regional self-government have the right to various sources of funding in order to be able to carry out their tasks, or to provide, to a greater or lesser degree, better public services to their users.

Key words: financing, local and regional self-government, decentralization, fiscal decentralization 